TOMASZ RACHWAL

Uniwersytet Pedagogiczny w Krakowie, Polska - Pedagogical University of Cracow, Poland

WIOLETTA KILAR

Uniwersytet Pedagogiczny w Krakowie, Polska - Pedagogical University of Cracow, Poland

ZYGMUNT KAWECKI

LXIV Liceum Ogólnokształcące im. Stanisława Ignacego Witkiewicza w Warszawie, Polska •

Stanisław Ignacy Witkiewicz High School no 44 in Warsaw, Poland

PIOTR WRóBEL

Akademia Górniczo-Hutnicza w Krakowie - AGH University of Science and Technology in Kraków

VII Liceum Ogólnokształcące w Krakowie - Zofia Nałkowska High School no 7 in Kraków

III Społeczne Liceum Ogólnokształcące w Krakowie, Polska - Community High School no 3 in Kraków, Poland

\title{
Edukacja w zakresie przedsiębiorczości w wychowaniu przedszkolnym, szkole podstawowej i szkołach średnich w świetle nowej podstawy programowej
}

\section{Entrepreneurship Education in Pre-School, Primary and Secondary Education in the New Core Curriculum}

Streszczenie: W obliczu coraz bardziej dynamicznych przemian społeczno-gospodarczych na świecie współcześnie wzrasta świadomość potrzeby kształcenia ekonomicznego od najmłodszych lat. Szczególną wagę ma wyposażanie młodzieży w wiedzę, która pozwala zrozumieć zjawiska społeczno-ekonomiczne, oraz w umiejętności praktyczne, a także kształtowanie postaw, dzięki którym możliwe jest wejście młodzieży w okres aktywności zawodowej i brania odpowiedzialności za swoje decyzje ekonomiczne. Dyskusja na temat roli edukacji szkolnej w tym względzie oraz treści kształcenia w zakresie przedsiębiorczości ma miejsce w Polsce od 2002 r., kiedy to wprowadzono do kształcenia ogólnego w szkołach ponadgimnazjalnych nowy przedmiot - podstawy przedsiębiorczości. Obecnie, ze względu na kolejną reformę edukacji, następują zmiany w kształceniu w zakresie podstaw przedsiębiorczości, które odbywać się będzie głównie na etapie szkoły średniej. Cele i treści kształcenia z zakresu przedsiębiorczości zostały także włączone w pewnym stopniu do edukacji w szkole podstawowej i wychowania przedszkolnego. Celem niniejszego artykułu jest zatem przedstawienie założeń nowej podstawy programowej z podstaw przedsiębiorczości dla szkół ponadpodstawowych, która zgodnie z harmonogramem wdrażania reformy będzie obowiązywać od roku szkolnego 2019/2020, oraz wskazanie możliwości kształtowania postaw przedsiębiorczych na niższych etapach edukacji. Przedstawiono także ważniejsze wnioski z przeprowadzonych konsultacji społecznych w tym zakresie. Analiza zapisów nowej podstawy programowej wskazuje, że jej wdrożenie powinno, zdaniem autorów, lepiej niż dotychczas sprzyjać edukacji ekonomicznej dzieci i młodzieży oraz kształtowaniu ich postaw przedsiębiorczych. Aby tak się stało, musi być spełnionych jednak szereg warunków, dlatego w końcowej części autorzy zawarli rekomendacje dla interesariuszy procesu kształcenia - instytucji kształcących i doskonalących nauczycieli, organów prowadzących, szkół i ich dyrektorów oraz nauczycieli.

Abstract: In the face of more and more dynamic socio-economic changes in the world, the awareness of the need for economic education from an early age is increasing. Particular attention is given to equipping young people with knowledge that allows them to understand social and economic phenomena 
surrounding them, as well as practical skills and shaping attitudes through which they can start a professional activity and take responsibility for their economic decisions. The discussion on the role of school education in this area and the learning content in the field of entrepreneurship has been present in Poland for many years, when in 2002 a new subject - basics of entrepreneurship - was introduced to general education in upper secondary schools. Currently, due to another reform of education, there are changes in entrepreneurship education, which will take place mainly at the secondary school stage. The goals and content of entrepreneurship education have also been incorporated to a certain extent in primary education and pre-school education. The aim of the article is therefore to present the assumptions of the new core curriculum from the "basics of entrepreneurship" for post-elementary schools, which in accordance with the reform implementation schedule will apply from the school year 2019/2020 and to indicate the possibility of shaping entrepreneurial attitudes at lower stages of education. Moreover, important conclusions from the public consultations in this regard were presented. The analysis of the provisions of the new core curriculum indicates that its implementation should, in the authors' opinion, be better conducive to economic education of children and youth and shaping their entrepreneurial attitudes. However, a number of conditions must be met, which is why in the final part, the authors made recommendations for stakeholders of the education process - education institutions for teachers, governing bodies, schools and their headmasters and teachers.

Słowa kluczowe: edukacja ekonomiczna; edukacja w zakresie przedsiębiorczości; konsultacje społeczne; podstawa programowa; postawy przedsiębiorcze; reforma systemu edukacji; system edukacji w Polsce

Keywords: core curriculum; economic education; entrepreneurship education; entrepreneurial attitudes; education system in Poland; public consultation; reform of the education system

Otrzymano: 30 marca 2018

Received: 30 March 2018

Zaakceptowano: 25 września 2018

Accepted: 25 September 2018

\section{Sugerowana cytacja/Suggested citation:}

Rachwał, T., Kilar, W., Kawecki, Z., Wróbel, P. (2018). Edukacja w zakresie przedsiębiorczości w wychowaniu przedszkolnym, szkole podstawowej i szkołach średnich w świetle nowej podstawy programowej, Przedsiębiorczość - Edukacja [Entrepreneurship - Education], 14, 389-424. DOI: $10.24917 / 20833296.14 .28$

\section{Wstęp}

Poznawanie i stopniowe rozumienie otaczającego świata następuje u dziecka od pierwszych dni życia. Każdego dnia dzieci nabywają nowe umiejętności i pogłębiają swoją wiedzę, co odbywa się zarówno w sposób formalny w przedszkolu czy później w szkole, jak i w sposób nieformalny w codziennym życiu. Również kształtowanie postaw przedsiębiorczych następuje stopniowo i odbywa się zarówno przez obserwację dorosłych, szczególnie rodziców i rodziny, jak i przez uczestnictwo w zajęciach przedszkolnych i szkolnych. Dlatego w wielu wysokorozwiniętych krajach, np. zachodniej i północnej Europy, zaczyna się ono bardzo wcześnie, z reguły już na etapie przedszkola. Wzorem są kraje skandynawskie, które, jak wynika z różnorodnych badań, m.in. PISA, osiągają wysokie efekty kształcenia, nie tylko w edukacji ekonomicznej. Należy podkreślić, że podstawowa wiedza o mechanizmach rynkowych i umiejętność podejmowania decyzji ekonomicznych są niezbędne w dzisiejszych czasach nie tylko - jak się powszechnie sądzi - w dorosłym życiu każdego człowieka, ale także już na etapach okresu dzieciństwa i dorastania, 
na których następuje przygotowanie do aktywności społecznej i gospodarczej. Edukacja ekonomiczna powinna więc zaczynać się jak najwcześniej i być stopniowo rozszerzana oraz pogłębiana na wyższych etapach edukacji - w szkole podstawowej i średniej aż do kształcenia uniwersyteckiego włącznie, tak aby wykształcić nie tylko kompetentnego, ale też przedsiębiorczego człowieka. Mówimy wszak tutaj o kształtowaniu jednej z kompetencji kluczowych w systemie edukacji (Zalecenie..., 2006; Kompetencje..., 2007; Kalita, 2014), stanowiącej fundament przygotowania do życia i zarazem jeden $\mathrm{z}$ ważniejszych czynników rozwoju społeczno-gospodarczego, na co zwraca uwagę wielu autorów (m.in. Borowiec-Gabryś, Kilar, Rachwał, 2018; Płaziak, Rachwał, 2014; Piróg, 2015; Rachwał, 2004, 2005, 2006; Wach, 2013, 2014, 2015; Zioło, 2006, 2007, 2009, 2012).

W nawiązaniu do powyższych przesłanek w artykule zmierzać się będzie do przedstawienia podstawowych założeń oraz celów, treści kształcenia i wymagań, które zaproponowano w nowej podstawie programowej w zakresie przedsiębiorczości w wychowaniu przedszkolnym, edukacji w szkole podstawowej oraz szkołach średnich w ramach przedmiotu podstawy przedsiębiorczości. Choć treści te w szkole podstawowej nie są realizowane $^{1} \mathrm{w}$ postaci osobnego przedmiotu, jest to ważny element kształcenia także na tym etapie edukacyjnym, wprowadzany w ramach innych przedmiotów. W artykule przedstawiono także ważniejsze wyniki konsultacji społecznych, które zostały przeprowadzone w trakcie prac nad nową podstawą programową, oraz uwagi, które zostały zgłoszone przez interesariuszy do rozważenia, w jakim zakresie uznano je za słuszne i jak się do nich ustosunkował zespół, który pracował nad podstawą programową do czteroletniego liceum, pięcioletniego technikum, branżowej szkoły I stopnia oraz szkół policealnych. Szczególny nacisk w artykule położony został na koncepcję realizacji przedmiotu podstawy przedsiębiorczości, który w szkołach średnich stanowi podstawowy filar szeroko rozumianej edukacji ekonomicznej.

Same zapisy nowej podstawy programowej nie zmienią jednak automatycznie rzeczywistości szkolnej, gdyż musi być spełnionych szereg warunków umożliwiających wprowadzenie jej w praktyce w życie, dlatego w końcowej części artykułu autorzy zawarli rekomendacje dla interesariuszy procesu kształcenia - instytucji kształcących i doskonalących nauczycieli, organów prowadzących, szkół i ich dyrektorów oraz - przede wszystkim - nauczycieli jako głównych osób odpowiedzialnych za kształcenie. Ze względu na dużą wagę dokumentu, jakim jest podstawa programowa, wytyczającego na kilka lub kilkanaście lat cele i treści kształcenia w zakresie przedsiębiorczości, oraz na złożoność problematyki nie jest możliwe pełne przedstawienie koncepcji zapisów nowej podstawy programowej w formie artykułu, dlatego w niniejszej pracy skoncentrowano się na ogólnych założeniach i najważniejszych zmianach w stosunku do dotychczas obowiązującej podstawy programowej.

\section{Przesłanki i fundamenty dyskusji o nowej podstawie programowej z przedsiębiorczości}

Nowa koncepcja kształcenia w zakresie przedsiębiorczości, ogłoszona w 2017 r. rozporządzeniem MEN (2017) do wychowania przedszkolnego i szkół podstawowych, a w 2018 r.

\footnotetext{
${ }^{1}$ Szersze omówienie nowej podstawy programowej od strony praktyki szkolnej będzie opublikowane w specjalnym komentarzu do podstawy programowej przygotowywanym przez autorów.
} 
(rozporządzenie MEN z 30.01.2018 oraz 26.07.2018) do szkół ponadpodstawowych (liceów, techników, szkół branżowych I dla absolwentów ośmioklasowej szkoły podstawowej oraz szkół branżowych II stopnia i szkół policealnych dla uczniów, którzy nie realizowali tego przedmiotu na wcześniejszych etapach edukacji), została opracowana przy uwzględnieniu nowego spojrzenia na procesy zachodzące w gospodarce oraz nowych kierunków i idei w zakresie dydaktyki przedsiębiorczości rozwijanych przez wyższe uczelnie. W szczególności wzięto pod uwagę wyniki wieloletnich dyskusji nad celami, treściami i metodami kształcenia $\mathrm{w}$ zakresie przedsiębiorczości, prowadzonymi w ramach organizowanych corocznie w Krakowie przez Zakład Przedsiębiorczości i Gospodarki Przestrzennej Uniwersytetu Pedagogicznego w Krakowie konferencji naukowych i zjazdów nauczycieli przedsiębiorczości (Rachwał, 2017a) oraz na łamach różnych czasopism, głównie „Przedsiębiorczość - Edukacja”. Jest to w praktyce jedyne czasopismo naukowe w Polsce dedykowane na stałe pracom z tego zakresu i otwarte corocznie, w każdym tomie, na publikowanie artykułów z problematyki edukacji w zakresie przedsiębiorczości, w tym także doświadczeń z praktyki szkolnej.

W wyniku dyskusji specjalnych prowadzonych podczas krakowskich konferencji i zjazdów, sformułowano przesłanki do zmian i kluczowe fundamenty dyskusji o nowej edukacji w zakresie przedsiębiorczości. Zostały one przedstawione w dużej mierze w pracy T. Rachwała (2017b). Warto jednak przypomnieć i podkreślić najważniejsze wnioski $\mathrm{z}$ tej dyskusji.

Po pierwsze, przedsiębiorczość jest jedną z ośmiu kompetencji kluczowych w europejskim systemie edukacji (ryc. 1), obok umiejętności posługiwania się językiem ojczystym, językiem obcym czy kompetencji matematycznych bądź informatycznych, stąd nie powinno być wątpliwości, że jej rola w każdym systemie edukacji i na każdym jej poziomie powinna być znacząca. Przedsiębiorczość to nie tylko zakładanie firmy - to jeden z ważnych, ale nie jedyny przejaw przedsiębiorczości - dlatego na potrzeby edukacji jest i powinna być rozumiana dużo szerzej, zgodnie z definicją przyjmowaną powszechnie w Europie (Zalecenie..., 2006; Kompetencje..., 2007; Kalita, 2014) oraz przez wielu autorów, m.in. Borowiec, Kilar, Rachwał, 2018; Rachwał, 2004, 2006; Wach, 2013, głównie jako zespół cech osobowości, które pozwalają na aktywne uczestnictwo w życiu społeczno-gospodarczym, przygotowując do dorosłego życia, ale także dalszej edukacji jako elementu kształtowania kariery zawodowej. Uczniowie szkół ponadpodstawowych, wkraczając w dorosłość, znajdą się w warunkach presji konkurencyjnej oraz zróżnicowanych wymagań rynku pracy. Powinni więc posiadać podstawową wiedzę nie tylko z zakresu nauk ścisłych, przyrodniczych i humanistycznych, ale także społecznych, a zwłaszcza ekonomicznych.

Po drugie, przyjęto, że przedsiębiorczość osób i organizacji, w tym także władz centralnych i samorządowych, odgrywa fundamentalną rolę w rozwoju społeczno-gospodarczym krajów oraz układów regionalnych (województw), ponadlokalnych (powiatów, obszarów funkcjonalnych - np. metropolitalnych) i lokalnych, tj. miast i gmin różnego typu (zob. Płaziak, Rachwał, 2014, 2015; Wach, 2015; Zioło, 2016), ma m.in. duże znaczenie w przeciwdziałaniu zjawisku bezrobocia oraz poszukiwaniu rozwiązań w przedsiębiorstwach w sytuacji deficytu pracowników o odpowiednikach kwalifikacjach na rynku pracy, stąd jej rola w edukacji wykracza poza korzyści osobiste (indywidualne). Przedsiębiorczość obywateli Polski odgrywa fundamentalną rolę w przyspieszaniu rozwoju gospodarczego opartego na rodzimym kapitale, z którego zyski są przeznaczane na konsumpcję głównie 
Ryc. 1. Kompetencje kluczowe w europejskim systemie edukacji

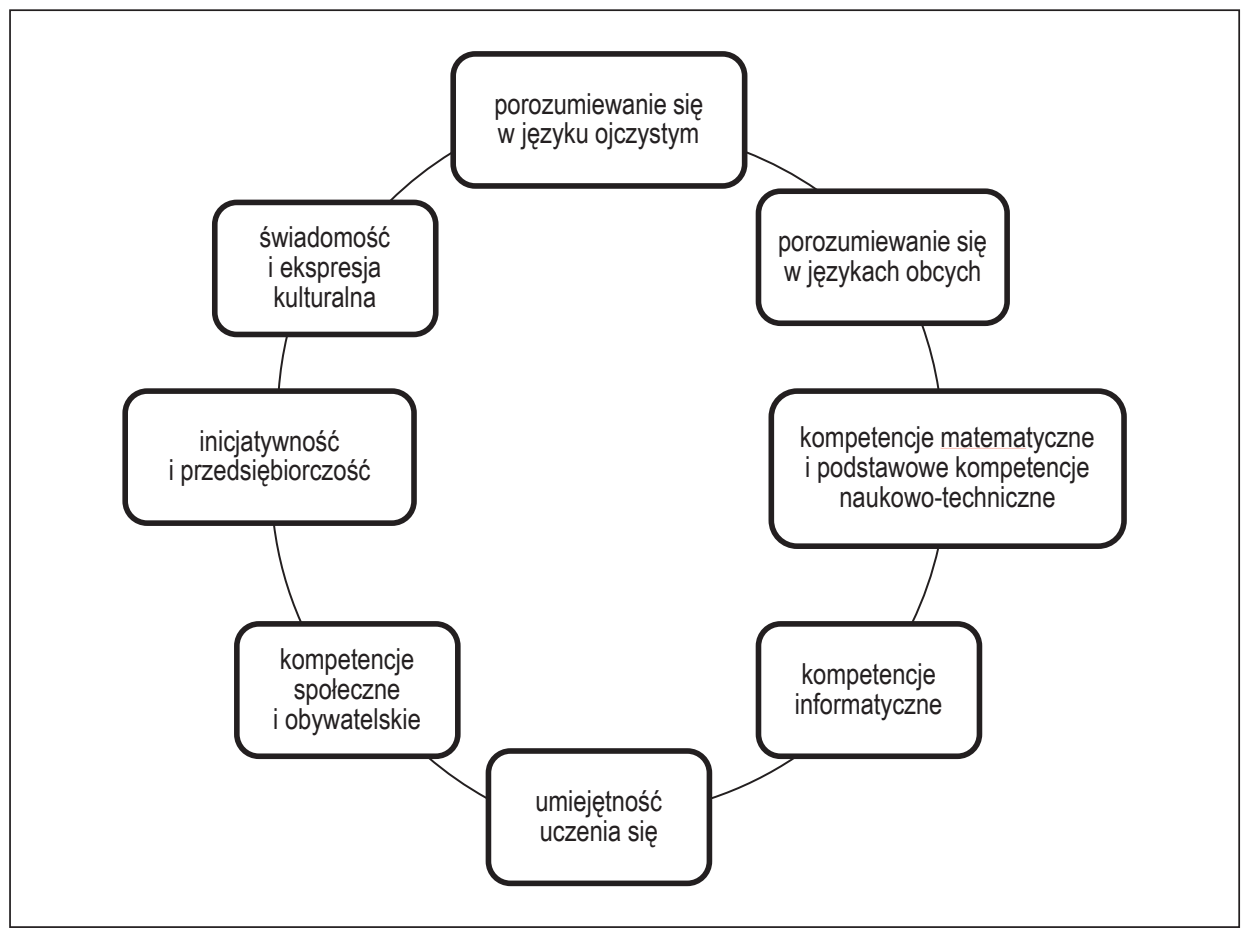

Źródło: opracowanie własne na podstawie Kompetencje... (2007)

w Polsce, reinwestowane głównie w kraju, dlatego dzięki przedsiębiorczości obywateli jest możliwe uruchomienie programów rozwoju gospodarczego kraju, opartych głównie na wykorzystaniu rodzimych zasobów. Edukacja w zakresie przedsiębiorczości winna więc być jednym $\mathrm{z}$ priorytetowych celów oświatowych na poziomie ogólnokrajowym.

Po trzecie, jak wynika z wieloletnich dyskusji i lektury różnych badań i raportów, należy przyznać, że Polska jest na niższym poziomie rozwoju edukacji ekonomicznej od innych wysokorozwiniętych krajów, dlatego zasadne jest podjęcie działań na rzecz wzmocnienia edukacji w tym zakresie i takich zmian, które przyczynią się do podniesienia jej poziomu. Dynamicznie zmieniające się uwarunkowania społeczno-gospodarcze związane z rozwojem cywilizacyjnym, postępem naukowym i budową gospodarki opartej na wiedzy wymagają również ciągłej modernizacji celów i treści kształcenia z różnych przedmiotów, aby wyposażać uczniów w wiedzę, umiejętności i postawy, które pozwolą im się odnaleźć w tym burzliwym otoczeniu, podlegającym permanentnym przemianom. Wynika stąd jednoznaczny wniosek, że zachowanie status quo w tym zakresie nie jest możliwe.

Ponadto w toku dyskusji uznano, że (por. Rachwał, 2017b):

- szerokie ujęcie przedsiębiorczości jako przedmiotu szkolnego jest konieczne, nie można więc ograniczać się tylko do kształtowania postaw przedsiębiorczych rozumianych jako chęć i zdolność do zakładania i prowadzenia własnego biznesu;

- zmiany powinny być raczej rewolucyjne niż ewolucyjne, gdyż w zakresie edukacji dla przedsiębiorczości zrobiono w ostatnich 15 latach, tj. od 2002 r., czyli wprowadzenia 
przedmiotu podstawy przedsiębiorczości do szkół ponadgimnazjalnych i elementów przedsiębiorczości do innych przedmiotów, głównie wiedzy o społeczeństwie w gimnazjum, kroki milowe, modyfikując korzystnie podstawę programową, szczególnie w 2008 r. (wdrożoną od 2012 r. - Rozporządzenie MEN..., 2012), dlatego nowa podstawa programowa powinna wykorzystywać dotychczasowe dobre doświadczenia w tym zakresie i utrzymać niektóre dobre zapisy z dotychczas obowiązującej starej podstawy programowej;

- podstawy przedsiębiorczości nie mogą być podstawami ekonomii ani podstawami finansów, ale wiedza ekonomiczna i finansowa jest podstawą zachowań przedsiębiorczych, dlatego powinna być elementem kształcenia w zakresie podstaw przedsiębiorczości;

- najważniejsze w kształceniu z podstaw przedsiębiorczości są wiedza, umiejętności i postawy związane $\mathrm{z}$ wykonywaniem pracy i funkcjonowaniem przedsiębiorstwa, w tym zakładaniem własnego biznesu;

- należy położyć większy nacisk na kształcenie umiejętności i postaw, a nie wyposażanie w wiedzę;

- nie jest korzystna realizacja przedmiotu zbyt wcześnie (1 klasa) ani zbyt późno (klasa maturalna);

- należy rozwiązać problem przeładowania treści w stosunku do liczby godzin, m.in. przez odpowiednie zaplanowanie korelacji międzyprzedmiotowych, i zbyt szerokiego, mało konkretnego ujęcia niektórych zapisów;

- w dotychczas obowiązującej podstawie brakuje precyzyjnego określenia treści kształcenia na rzecz definiowania ich przez efekty kształcenia, nie zawsze oddających te treści, konieczne jest wyeliminowanie niejasnych sformułowań i doprecyzowanie wymagań szczegółowych w języku efektów kształcenia;

- konieczna jest korekta istniejących zapisów podstawy programowej podstaw przedsiębiorczości w zakresie usunięcia zbędnych powtórzeń pomiędzy różnymi etapami szkolnymi, przesunięcie zbyt banalnych treści ze szkoły średniej do podstawowej (poziom dawnego gimnazjum), a zbyt trudnych z wygaszanego gimnazjum do szkoły średniej;

- niezbędne jest uzupełnienie przedmiotu podstawy przedsiębiorczości o treści związane z ekonomią społeczną i społeczną odpowiedzialnością biznesu, rolą firm rodzinnych, problematyką zarządzania ludźmi i analizą rynku (otoczenia) oraz wzmocnienie treści związanych z umiejętnością zbierania i analizowania danych o rozwoju gospodarczym i funkcjonowaniu przedsiębiorstw, a także w zakresie ochrony klienta usług finansowych;

- należy wpisać do tzw. zaleceń (warunków realizacji) kwestię ćwiczeń terenowych jako jedną z niezbędnych form kształcenia.

Zespół ekspertów opracowujący nową podstawą programową starał się wdrażać powyższe postulaty w praktyce. Nie osiągnięto jedynie efektu w postaci wprowadzenia realizacji przedmiotu podstawy przedsiębiorczości w wersji rozszerzonej, z możliwością jego zdawania na maturze (jako nieobowiązkowy przedmiot do wyboru), co było formułowane w trakcie dyskusji już od wielu lat jako istotny postulat (por. Bartoń, 2005; Rachwał i in., 2008). Wskazywano również na zasadność utrzymania fakultatywnego przedmiotu ekonomia w praktyce w szkołach średnich. W obliczu zmiany koncepcji kształcenia na tym poziomie przedmioty fakultatywne nie zostały uwzględnione jednak w nowych ramowych planach nauczania. Istotnym wyzwaniem stało się więc przeniesienie niektórych 
ciekawych i koniecznych zapisów z tego przedmiotu do nowej podstawy programowej z podstaw przedsiębiorczości.

Warto zwrócić uwagę także na jeszcze jeden element dyskusji - przygotowanie nauczycieli przedmiotu podstawy przedsiębiorczości. W ciągu 15 lat od wprowadzenia tego przedmiotu przygotowano odpowiednio liczną kadrę nauczycieli przedsiębiorczości nie tylko na studiach podyplomowych kwalifikacyjnych z przedsiębiorczości, ale także na dwuprzedmiotowych studiach nauczycielskich (np. geografia z przedsiębiorczością), a w świetle prowadzonych badań należy stwierdzić coraz lepsze przygotowania nauczycieli do prowadzenia tego przedmiotu (pomimo pewnych słabości i braków kadrowych na początku XXI w., por. Tracz, Rachwał, 2007). Formułowane czasem obiegowe generalizujące opinie o niskim przygotowaniu i zaangażowaniu nauczycieli przedsiębiorczości należy uznać za krzywdzące. Godne podkreślenia w tym miejscu jest stale rosnące zainteresowanie uczniów udziałem w olimpiadach, takich jak Olimpiada Wiedzy Ekonomicznej oraz Olimpiada Przedsiębiorczości oraz inne olimpiady rozwijające postawy przedsiębiorcze i wiedzę z zakresu przedmiotu, co świadczy o dużym zaangażowaniu nauczycieli w przygotowanie uczniów, choć start w takich olimpiadach nie daje zwolnienia $\mathrm{z}$ matury z najwyższym wynikiem ani takich preferencji rekrutacyjnych na uczelnie wyższe, jak w przypadku olimpiad z przedmiotów maturalnych. Należy też podkreślić, że wielu nauczycieli przedsiębiorczości pełni funkcję doradców zawodowych w szkołach, co pozwala na odpowiednie powiązanie treści kształcenia $\mathrm{z}$ tego przedmiotu $\mathrm{z}$ bardzo ważną kwestią rozpoznania predyspozycji zawodowej (por. Piróg, 2015; Piróg, Rachwał, 2018) oraz projektowania ścieżki kariery zawodowej. Należy więc uznać, że polski system oświaty dysponuje dobrymi zasobami ludzkimi do kształcenia w zakresie przedsiębiorczości.

\section{Przedsiębiorczość w wychowaniu przedszkolnym}

i edukacji wczesnoszkolnej (klasy I-III)

Jak wspomniano wyżej, edukacja ekonomiczna powinna zaczynać się jak najwcześniej, dlatego treści z zakresu przedsiębiorczości wdrożono w pewnym zakresie w wychowanie przedszkolne i kształcenie na etapie szkoły podstawowej w ramach różnych przedmiotów, w tym także edukacji zintegrowanej na etapie kształcenia wczesnoszkolnego w klasach I-III. Chociaż cele i treści w zakresie przedsiębiorczości na tych etapach edukacji nie są realizowane w postaci osobnego przedmiotu, jest to ważny element kształcenia, dlatego w nowej podstawie programowej w wychowaniu przedszkolnym i edukacji w szkole podstawowej starano się uwzględnić takie cele ogólne i wymagania szczegółowe, które sprzyjałyby kształtowaniu postaw przedsiębiorczych dzieci. Decyzje w tym zakresie nie należały do zespołu ds. podstawy programowej z przedsiębiorczości, ale do zespołów odpowiedzialnych za wychowanie przedszkolne czy poszczególne przedmioty, niemniej jednak z własnej inicjatywy lub jako odpowiedź na propozycje zespołu ds. przedsiębiorczości wprowadziły one pewne treści z tego zakresu.

I tak w podstawie programowej wychowania przedszkolnego dla przedszkoli i innych form wychowania przedszkolnego (Rozporządzenie MEN z 14 lutego 2017...) uwzględniono z zakresu przedsiębiorczości:

- w emocjonalnym obszarze rozwoju dziecka zapisano efekty związane z wczuwaniem się dziecka w emocje i uczucia osób z najbliższego otoczenia, co jest podstawą kształtowania dobrych relacji interpersonalnych; 
- w społecznym obszarze rozwoju dziecka zapisano takie wymagania szczegółowe, jak: [dziecko] przejawia poczucie własnej wartości, szanuje wypowiedzi innych dzieci, czeka na swoją kolej; respektuje prawa i obowiązki swoje oraz innych dzieci; komunikuje się z dziećmi i osobami dorosłymi, wykorzystując komunikaty werbalne i pozawerbalne oraz rozumie ich znaczenie $\mathrm{w}$ porozumiewaniu się $\mathrm{z}$ innymi, stanowiące fundament samooceny w zakresie własnej wartości, a później własnych słabych i mocnych stron oraz współdziałania $\mathrm{z}$ innymi;

- w poznawczym obszarze rozwoju dziecko przez identyfikację zawodów wykonywanych przez rodziców wskazuje, czym zajmuje się osoba wykonująca dany zawód, oraz jakie jest jego znaczenie dla samego dziecka, rodziny i społeczeństwa.

Zapisy sprzyjające kształtowaniu postaw przedsiębiorczych i wprowadzające podstawową wiedzę ekonomiczną zostały uwzględnione w podstawie programowej edukacji wczesnoszkolnej. W zakresie społecznego obszaru rozwoju założono, że uczeń osiąga m.in. umiejętności: identyfikowania się z grupami społecznymi, które dziecko reprezentuje, oceniania własnego postępowania i korzystania z tej oceny w pracy nad sobą, współdziałania, współpracy oraz samodzielnej organizacji pracy w małych zespołach, samodzielnego wyrażania swoich oczekiwań i potrzeb społecznych, tworzenia relacji społecznych; samodzielnej organizacji czasu przeznaczonego na odpoczynek indywidualnie i w grupie oraz rozwoju zainteresowań. W zakresie poznawczego obszaru rozwoju uczeń osiąga umiejętność obserwacji faktów i zjawisk, nie tylko przyrodniczych i społecznych, ale także gospodarczych, oraz umiejętność formułowania wniosków i spostrzeżeń z nich wynikających. Jest to podstawa do dalszego rozwijania w okresie późniejszym umiejętności analizowania i oceny zjawisk oraz procesów występujących w gospodarce.

W zakresie edukacji polonistycznej przyjęto, że uczeń potrafi napisać notatkę, życzenia, ogłoszenie, zaproszenie, podziękowanie, przeprosiny, list, a do pisania krótkich tekstów wykorzystuje także komputer, co warunkuje dalszą możliwość rozwijania umiejętności przygotowania aplikacji do pracy czy prowadzenie korespondencji biznesowej. Z kolei w edukacji matematycznej założono, że uczeń wykonuje obliczenia pieniężne, zamienia złotówki na grosze i odwrotnie, wyjaśnia, czym są banknot i bilon (moneta), wie, do czego służy konto bankowe, dokonuje prostych obliczeń zmian salda na koncie, uwzględniając typowe codzienne wydatki i dochody w rodzinie, oraz rozumie, że płatności można wykonywać nie tylko za pomocą banknotów i bilonu, ale także w postaci elektronicznej. Są to więc podstawy wiedzy i umiejętności związanych z finansami. W edukacji społecznej przyjęto, że uczeń identyfikuje się z grupą społeczną, do której należy: rodzina, klasa w szkole, drużyna sportowa itp., a także ze społecznością lokalną i narodem, respektuje normy i reguły postępowania w tych grupach; przyjmuje konsekwencje swojego uczestnictwa w grupie i własnego w niej postępowania, prezentując swym zachowaniem wartości, takie jak: sprawiedliwość, obowiązkowość i odpowiedzialność, rozumie, iż wszyscy ludzie posiadają prawa i obowiązki, zna własne prawa i obowiązki, przestrzega ich i stosuje je w codziennym życiu oraz przedstawia siebie i grupę, z którą się identyfikuje. W wyniku kształcenia z tego obszaru uczeń będzie także znał zawód i miejsce pracy rodziców, stosował we właściwej sytuacji słowa: „porozumienie” i „umowa”, wykorzystywał pracę zespołową w procesie uczenia się, w tym przyjmując rolę lidera zespołu, oraz komunikował się za pomocą nowych technologii. Są to umiejętności będące podstawą funkcjonowania w każdym zespole i miejscu nauki czy pracy. Choć wydaje się to zbyt odległe, to także w edukacji przyrodniczej zapisano wymagania, które są związane 
z przedsiębiorczością. Przyjęto, że uczeń potrafi określać położenie i warunki naturalne swojej miejscowości i okolicy oraz opisywać, nie tylko charakterystyczne formy terenu i składniki przyrody, ale także najważniejsze zakłady pracy, w tym ważniejsze przedsiębiorstwa produkcyjne i usługowe. Powinien też umieć przedstawić w krótkiej wypowiedzi ustnej sektory gospodarki charakterystyczne dla Polski. W zakresie edukacji technicznej rozwija się umiejętność oceniania projektów lub prac, przy wykorzystaniu poznanych i zaakceptowanych wartości, takich jak systematyczność działania, pracowitość, konsekwencja, gospodarność, oszczędność, umiar w odniesieniu do korzystania z czasu, materiałów, narzędzi i urządzeń. Są to wartości niezbędne w każdej pracy i działalności biznesowej. Istotne miejsce w edukacji wczesnoszkolnej zajmują ponadto kwestie etyki życia społecznego i po części także gospodarczego w ramach lekcji religii i etyki.

\section{Przedsiębiorczość w szkole podstawowej w drugim etapie edukacyjnym (klasy IV-VIII)}

W większym stopniu cele, treści i wymagania z zakresu przedsiębiorczości mogły być wprowadzone w drugim etapie edukacyjnym nowej ośmioklasowej szkoły podstawowej, obejmującym klasy IV-VIII. Uwzględniono je nie tylko na zajęciach z wiedzy o społeczeństwie, geografii czy języka polskiego, ale także z kilku innych przedmiotów.

W podstawie programowej dla języka polskiego w celach kształcenia - wymaganiach ogólnych - podano szereg ważnych z punktu widzenia kształtowania postawy przedsiębiorczej zapisów, takich jak kształcenie umiejętności porozumiewania się (słuchania, czytania, mówienia i pisania) w różnych sytuacjach prywatnych i publicznych, w tym także z osobami doświadczającymi trudności w komunikowaniu się, rozpoznawanie intencji rozmówcy oraz wyrażanie intencji własnych, rozwijanie umiejętności samodzielnego docierania do informacji, dokonywania ich selekcji i krytycznej oceny, rozwijanie umiejętności efektywnego posługiwania się technologią informacyjną w poszukiwaniu, porządkowaniu i wykorzystywaniu pozyskanych informacji, kształcenie nawyków systematycznego uczenia się oraz porządkowania zdobytej wiedzy i jej pogłębiania. Z kolei w wymaganiach szczegółowych dla tego przedmiotu przyjęto, że uczeń potrafi tworzyć spójne wypowiedzi ustne i pisemne w różnych formach gatunkowych, w tym podanie, życiorys, CV i list motywacyjny oraz przemówienie, a także rozwija umiejętność krytycznego myślenia i formułowania opinii.

W wyniku realizacji lekcji chemii uczeń powinien przestrzegać zasad bezpieczeństwa i higieny pracy oraz stosować przepisy prawa dotyczące ochrony środowiska, pozyskiwać i przetwarzać informacje z różnorodnych źródeł z wykorzystaniem technologii informacyjno-komunikacyjnych, oceniać wiarygodność uzyskanych danych, konstruować wykresy, tabele i schematy na podstawie dostępnych informacji. Umiejętności te $\mathrm{z}$ powodzeniem mogą być więc wykorzystane do innych danych i informacji, np. gospodarczych.

Szereg zapisów istotnych dla kształcenia postawy przedsiębiorczej znalazło się także $\mathrm{w}$ treściach $\mathrm{z}$ informatyki. W wymaganiach ogólnych zapisano rozwijanie kompetencji społecznych, takich jak komunikacja i współpraca w grupie w tym w środowiskach wirtualnych, udział w projektach zespołowych oraz organizację i zarządzanie projektami, natomiast w wymaganiach szczegółowych przyjęto, że w wyniku kształcenia uczeń przestrzega zasad bezpieczeństwa i higieny pracy, uczestniczy w zespołowym rozwiązaniu problemu, 
posługując się technologią, identyfikuje i docenia korzyści płynące ze współpracy nad wspólnym rozwiązywaniem problemów, bierze udział w różnych formach współpracy oraz projektuje, tworzy i prezentuje efekty wspólnej pracy. Są to zatem efekty odnoszące się bezpośrednio do kształcenia umiejętności pracy zespołowej.

Kształtowaniu umiejętności analizy i prezentacji danych (a więc także gospodarczych), sprzyjają zapisy z zakresu matematyki. W wymaganiach szczegółowych dla tego przedmiotu znajdują się punkty mówiące o tym, że uczeń interpretuje dane przedstawione za pomocą tabel, diagramów słupkowych i kołowych oraz wykresów, tworzy diagramy słupkowe i kołowe oraz wykresy liniowe na podstawie zebranych przez siebie danych lub danych pochodzących z różnych źródeł.

Z kolei w ramach edukacji dla bezpieczeństwa w świetle podstawy programowej uczeń kształtuje umiejętności komunikacji interpersonalnej istotne dla zdrowia i bezpieczeństwa (odmowa, zachowania asertywne, negocjowanie), a w ramach lekcji techniki nabywa poczucia odpowiedzialności za wyniki pracy grupowej oraz kształtuje umiejętność współpracy i podejmuje różne role w pracy w zespole.

Szeroką podbudowę do wiedzy ekonomicznej daje historia, w ramach której w wymaganiach szczegółowych zapisano szereg efektów kształcenia związanych z historią gospodarczą, takich jak: uczeń opowiada o Eugeniuszu Kwiatkowskim i budowie Gdyni, omawia zjawiska świadczące o postępie gospodarczym, charakteryzuje najważniejsze przejawy rewolucji przemysłowej, omawia skutki światowego kryzysu gospodarczego na ziemiach polskich, ocenia osiągnięcia gospodarcze II Rzeczypospolitej, a zwłaszcza powstanie Gdyni, magistrali węglowej i Centralnego Okręgu Przemysłowego, charakteryzuje bezpośrednie skutki II wojny światowej, wyróżniając także następstwa gospodarcze, przedstawia cele i główne etapy rozwoju Unii Europejskiej, charakteryzuje przemiany społeczno-polityczne w Europie Środkowo-Wschodniej w latach 1989-1991, opisuje kluczowe przemiany ustrojowe w latach 1989-1997 oraz charakteryzuje przemiany nie tylko społeczno-polityczne i kulturowe, ale także gospodarcze lat 90. XX w.

Ważne miejsce w edukacji w szkole podstawowej w zakresie przedsiębiorczości zajmuje wiedza o społeczeństwie. W wymaganiach ogólnych z tego przedmiotu ujęto szereg umiejętności związanych z komunikacją interpersonalną i współpracą z innymi. W wymaganiach szczegółowych ujęto m.in. następujące zapisy związane z postawą przedsiębiorczą: uczeń przedstawia zasady komunikowania się, wyjaśnia zasady skutecznej autoprezentacji - kształtowania swojego wizerunku w nowym środowisku, rozumie korzyści, jakie przynosi efektywna współpraca, zna różne formy współpracy w grupie i w nich uczestniczy, rozpoznaje sytuacje wymagające podjęcia decyzji indywidualnej i grupowej, wyjaśnia i stosuje podstawowe sposoby podejmowania wspólnych decyzji, podaje przykłady trudnych społecznie sytuacji, w których należy zachować się asertywnie, rozumie, że konflikt w grupie może wynikać z różnych przyczyn, definiuje konflikt i wymienia rodzaje konfliktów, przedstawia sposoby rozwiązywania konfliktów i określa ich zalety i wady, stosuje optymalne sposoby rozwiązywania określonych konfliktów. Jak widać po przywołanych zapisach, przedmiot ten przejął w znacznej mierze odpowiedzialność za kształtowanie umiejętności w zakresie komunikacji interpersonalnej, pracy zespołowej i rozwiązywania konfliktów, co dotychczas występowało także częściowo w podstawach przedsiębiorczości. Dzięki temu jest możliwość realizacji na lekcjach przedsiębiorczości wielu innych ważnych treści. Jest to także zgodne z opiniami płynącymi z debat i dyskusji, że umiejętności w zakresie komunikacji interpersonalnej powinny być już w znacznym 
stopniu rozwinięte właśnie szkole podstawowej, a nie dopiero w szkole średniej. Ponadto zapisy dotyczące tego przedmiotu przewidują, że uczeń charakteryzuje oczekiwane kompetencje wybranych kategorii społeczno-zawodowych i ich miejsce na rynku pracy oraz szereg wymagań związanych z gospodarczymi aspektami funkcjonowania samorządu gminnego (w tym główne źródła przychodów i kierunki wydatków w budżecie gminy) oraz korzyściami związanymi z obecnością Polski w Unii Europejskiej dla pracowników i osób podróżujących. Warto też uwypuklić zapisy dotyczące cnót obywatelskich, gdzie obok m.in. odpowiedzialności, troski o dobro wspólne, aktywności, solidarności, roztropności, tolerancji, zapisano także jako cnotę właśnie przedsiębiorczość.

Duże znaczenie w kształtowaniu postaw przedsiębiorczych i rozwijaniu wiedzy i umiejętności o charakterze ekonomicznym ma też edukacja geograficzna (por. Borowiec, Rachwał, 2011). W celach kształcenia - wymaganiach ogólnych - zapisano umiejętność określania związków i zależności między poszczególnymi elementami środowiska przyrodniczego, społeczno-gospodarczego i kulturowego, oceniania zjawisk i procesów społeczno-kulturowych oraz gospodarczych zachodzących w Polsce i w różnych regionach świata; kształtowanie poczucia dumy z piękna ojczystej przyrody i dorobku narodu, w tym sukcesów polskich przedsiębiorstw na arenie międzynarodowej. Z kolei w wymaganiach szczegółowych założono wyposażenie w wiedzę i umiejętności związane z identyfikacją i analizą procesów gospodarczych w Polsce i innych krajach świata, np.: [uczeń] wykazuje znaczenie poszczególnych sektorów gospodarki w rozwoju kraju oraz określa różnice w strukturze zatrudnienia ludności w Polsce i w wybranych państwach europejskich, porównuje wielkość bezrobocia w Polsce i innych krajach europejskich oraz określa jego przyczyny i skutki w Polsce, wyjaśnia przyczyny zmian w strukturze przemysłu Polski; podaje przykłady różnych rodzajów usług w Polsce oraz ocenia znaczenie transportu i łączności dla jakości życia mieszkańców i rozwoju gospodarczego naszego kraju, ocenia możliwości rozwoju gospodarki morskiej w Polsce, podaje przykłady osiągnięć Polaków w różnych dziedzinach życia społeczno-gospodarczego oraz sukcesów polskich przedsiębiorstw na arenie międzynarodowej. Istotne znaczenie ma także kształcenie umiejętności identyfikacji i analizy relacji między elementami przestrzeni społeczno-gospodarczej. Służą temu następujące zapisy podstawy programowej: [uczeń] wykazuje wpływ przemian politycznych i gospodarczych w Polsce po 1989 r. na zmiany struktury zatrudnienia na przykładzie konurbacji katowickiej i aglomeracji łódzkiej, identyfikuje związki między przebiegiem autostrad i dróg ekspresowych a lokalizacją przedsiębiorstw przemysłowych, centrów logistycznych i handlowych w obszarze metropolitalnym Wrocławia oraz między transportem morskim a lokalizacją inwestycji przemysłowych i usługowych na przykładzie Trójmiasta. W trakcie lekcji dotyczących własnego regionu i „małej ojczyzny” zwraca się uwagę na główne cechy gospodarki własnego regionu na podstawie wyszukanych danych statystycznych i map tematycznych oraz na atrakcyjność „małej ojczyzny” jako miejsca zamieszkania i działalności gospodarczej na podstawie informacji wyszukanych w różnych źródłach. Duży walor kształcący w zakresie procesów społeczno-gospodarczych na świecie mają zapisy odnoszące się do gospodarek poszczególnych krajów europejskich i pozaeuropejskich, takie jak: [uczeń] przedstawia znaczenie nowoczesnego przemysłu i usług w gospodarce na przykładzie Francji, charakteryzuje przemiany w strukturze przemysłu w Niemczech na przykładzie Nadrenii Północnej-Westfalii, rozumie problemy polityczne, społeczne i gospodarcze Ukrainy, charakteryzuje gospodarkę Rosji, ocenia znaczenie warunków przyrodniczych i czynników 
społeczno-kulturowych w tworzeniu nowoczesnej gospodarki Japonii, przedstawia kierunki rozwoju gospodarczego Chin oraz ocenia ich znaczenie w gospodarce światowej; określa możliwości rozwoju gospodarczego Indii oraz przedstawia kontrasty społeczne w tym kraju, charakteryzuje region Bliskiego Wschodu pod względem cech kulturowych oraz zasobów ropy naftowej i poziomu rozwoju gospodarczego, określa rolę tradycyjnych i nowoczesnych działów gospodarki w rozwoju wybranych krajów Afryki, na przykładzie Doliny Krzemowej wyjaśnia przyczyny rozwoju technopolii oraz jej znaczenie w rozwoju gospodarki opartej na wiedzy, korzystając z danych statystycznych, określa rolę Stanów Zjednoczonych w gospodarce światowej, identyfikuje prawidłowości w rozmieszczeniu ludności i główne cechy gospodarki Australii na tle warunków przyrodniczych.

Zapisy te oznaczają, że podstawy zachowań przedsiębiorczych są już wprowadzane na najwcześniejszych etapach edukacji i obejmują prawie wszystkie przedmioty w szkole podstawowej. Dotyczy to głównie kształtowania kompetencji osobistych związanych z myśleniem przedsiębiorczym i samorozwojem, kompetencji w zakresie komunikacji interpersonalnej i pracy zespołowej, umiejętności matematyczno-informatyczno-technicznych przydatnych w pracy i analizie danych gospodarczych oraz szeroką wiedzą na temat uwarunkowań rozwoju społeczno-gospodarczego Polski i innych krajów.

\section{Konsultacje społeczne nowej podstawy programowej z podstaw przedsiębiorczości}

Prekonsultacje i konsultacje społeczne ogłoszone przez Ministerstwo Edukacji Narodowej w 2017 r. dotyczyły nowej podstawy programowej ze wszystkich przedmiotów dla różnych rodzajów szkół. Objęły one także przedmiot podstawy przedsiębiorczości. Interesariuszami, którzy wypowiedzieli się na temat podstaw przedsiębiorczości, były urzędy, instytucje rządowe, instytucje finansowe oraz stowarzyszenia i inne organizacje pozarządowe. Głos zabrały także osoby prywatne, głównie doświadczeni nauczyciele podstaw przedsiębiorczości. Podczas pracy nad nową podstawą przedmiotową zastosowano po raz pierwszy tzw. etap wstępny, którym były prekonsultacje społeczne dotyczące projektu nowej podstawy programowej, a następnie konsultacje. Na obu etapach każdy z ww. interesariuszy mógł zgłosić swoje uwagi przez stronę internetową na specjalnym formularzu, a instytucje wskazane oficjalnie w ramach procedury konsultacji przesyłały swoje stanowiska w pismach adresowanych do MEN-u. Ogólnie można powiedzieć, że formułowane opinie były zbieżne z opiniami wygłaszanymi na krakowskich konferencjach dla nauczycieli przedsiębiorczości w latach 2015 i 2016.

Warto podkreślić, że dla autorów praca nad dokumentem wprowadzającym nową podstawę programową z przedsiębiorczości była $\mathrm{z}$ jednej strony dużym wyzwaniem, a z drugiej strony - zadaniem niezwykle interesującym, traktowanym jako tworzenie czegoś, co wpłynie na podniesienie świadomości ekonomicznej i postaw przedsiębiorczych młodego pokolenia oraz pozwoli uwierzyć wielu sceptycznie nastawionym interesariuszom systemu oświaty w sens prowadzenia i nauczania treści przedmiotu, jakim są podstawy przedsiębiorczości, uważanego przez wielu jako mało istotny element procesu kształcenia.

Celem zespołu opracowującego projekt nowej podstawy programowej w zakresie przedsiębiorczości było stworzenie jednolitego i spójnego dokumentu, który w sposób jasny przybliża uczniowi, czym jest przedsiębiorczość w obliczu warunków, jakie stawia 
przed nim gospodarka rynkowa, dlatego nie tylko przyjęto wyżej przedstawione wnioski $\mathrm{z}$ wieloletnich dyskusji, ale też z zainteresowaniem, otwartością i uwagą przeanalizowano wszystkie nadesłane uwagi.

Zgłoszone uwagi na etapie prekonsultacji były w większości trafne. Głównie postulowały one uzupełnienie treści kształcenia, ale nie uwzględniały wskazówek, które omawiałyby sposoby ich realizacji w warunkach nakreślonych przez rozporządzenie MEN w sprawie ramowych planów nauczania (rozporządzenie MEN z 28.03.2017) oraz zasad konstrukcji dokumentu, jakim jest podstawa programowa wynikających z odpowiednich przepisów prawnych. Odpowiedź na zgłaszane uwagi często stanowiła poważne wyzwanie, ponieważ zgłoszone propozycje były słuszne i wprowadzały nowe i ciekawe tematy do edukacji podstaw przedsiębiorczości, bardzo często wykraczały one jednak poza normy czasowe (tylko dwie godziny w cyklu kształcenia, czyli po jednej godzinie tygodniowo w liceum, technikum i branżowej szkole I stopnia) lub zbytnio rozszerzały treści nauczania. Przykładowo Ministerstwo Finansów i Rozwoju w kilku punktach proponowało znaczne rozszerzenie wiedzy o finansach. Zespół wyszedł jednak z założenia, że zagadnienia zasugerowane przez ministerstwo mogłyby być zrealizowane na zajęciach dodatkowych lub po wprowadzeniu przedmiotu o nazwie finanse, gdyż dopisanie tylu punktów do przedmiotu podstawy przedsiębiorczości wykluczyłoby w praktyce realizację innych treści. Proponowano także zmianę nazwy przedmiotu (wniosek Fundacji Pomyśl o Przyszłości). Była to ciekawa propozycja, ale po dyskusjach stwierdzono, że zmiana nazwy przedmiotu podstawy przedsiębiorczości na podstawy wiedzy o gospodarce i przedsiębiorczości nie jest wskazana, gdyż nie o wiedzę w tym wypadku chodzi, ale o kształtowanie postaw przedsiębiorczych, dla których oczywiście podstawą jest wiedza o gospodarce. Ponadto o utrzymaniu starej nazwy przedmiotu zdecydowano w ogłoszonym wcześniej rozporządzeniu MEN. Na etapie prekonsultacji kilka osób prywatnych zasugerowało zmianę liczby godzin przeznaczonych na nauczanie podstaw przedsiębiorczości oraz przerzucenie nauczanych treści do innych klas w ramach czteroletniego liceum i pięcioletniego technikum. Nie przyjęto także uwagi odnoszącej się do wprowadzenia na powrót przedmiotu ekonomia w praktyce, gdyż wykraczało to poza kompetencje zespołu. Z uwagi na odgórnie narzucone wytyczne, tj. rozporządzenie MEN w sprawie ramowych planów nauczania z 28 marca 2017 r., zespół nie miał możliwości wprowadzenia tych uwag.

Szereg uwag na etapie prekonsultacji wykraczał poza ustalane ramy podstaw przedsiębiorczości i jest możliwy do realizacji w ramach innych przedmiotów. Proponowano m.in. (Urząd Marszałkowski Województwa Małopolskiego) wprowadzenie selekcji klasyfikacji zawodów oraz problematykę wyboru zawodu. Taka problematyka powinna być jednak realizowana w ramach doradztwa zawodowego. Uwaga obejmująca elementy związane z instytucjonalną obsługą rynku pracy w odniesieniu do osób poszukujących pracy powinna być zrealizowana w pewnym stopniu na przedmiocie wiedza o społeczeństwie. Fundacja Pomyśl o Przyszłości zasugerowała rozszerzenie przedmiotu o wiedzę obejmującą funkcjonowanie różnych grup społecznych oraz znajomość podziału budżetu domowego. Te treści będą realizowane w ramach nowej podstawy programowej z wiedzy o społeczeństwie. Ta sama Fundacja zaproponowała wprowadzenie zagadnień związanych z gospodarką globalną. Uznano jednak, że te treści są realizowane w ramach nowej podstawy programowej z geografii. Fundacja przesłała również uwagi dotyczące wprowadzenia nowych pojęć oraz określeń, takich jak: biznes aortowy i wtórny, efekt skali, wartość dodana lub koszty korporacyjne. Uznano je jednak za zbyt specjalistyczne i odrzucono. 
Kolejna uwaga, tym razem od osób prywatnych, dotyczyła rozszerzenia wiedzy dotyczącej komunikacji interpersonalnej. Treści te realizowane są w znacznej mierze na przedmiocie wiedza o społeczeństwie, już w ósmej klasie szkoły podstawowej, dlatego w podstawach przedsiębiorczości są punkty odnoszące się do wykorzystania wcześniej nabytych umiejętności w zakresie komunikacji. Mając na uwadze wnioski z wcześniejszych dyskusji, dążono bowiem do nieprzeładowywania treści kształcenia i przenoszenia na niższe poziomy edukacji tego, co może być w nich z powodzeniem realizowane.

Zaakceptowano natomiast uwagi dotyczące problematyki bankowości elektronicznej nadesłane przez Ministerstwo Finansów i Rozwoju oraz instytucje finansowe. Uwzględniono także uwagi sugerujące podkreślenie aspektów etycznych i prospołecznych (nadesłane m.in. przez Grupę Zagranica).

W ramach prekonsultacji nadesłały swoje uwagi osoby prywatne, jak można sądzić nauczyciele z bogatym doświadczeniem zawodowym, którzy mają za sobą wiele lat pracy w nauczaniu podstaw przedsiębiorczości. Uwagi dotyczyły trudności w realizacji treści przedmiotu w salach wyposażonych w komputery i sprzęt multimedialny. Chociaż widać postępującą informatyzację szkół, to organizowanie lekcji w klasach wyposażonych $\mathrm{w}$ komputery pozostawiono decyzji nauczyciela pracującego w danej szkole - w nowej podstawie nie ma zapisów, które by obligowały do prowadzenia zajęć w pracowni komputerowej, choć przy realizacji niektórych tematów byłoby to wskazane. Zatem jeśli szkoła jest przygotowana od strony technicznej do realizacji treści nauczania podstaw przedsiębiorczości z dostępem do komputerów i Internetu, to należy tak postępować, aby wykorzystać to dobro. Do dyspozycji nauczycieli zostawiono także realizację poszerzonej koncepcji marketingu, co było jednym z postulatów. W podstawie programowej ograniczono się więc do podstawowej koncepcji „4P”. Osoby prywatne sugerowały rozszerzenie wiedzy z przedmiotu o spółki europejskie, jednak z uwagi na ich marginalne znaczenie w europejskiej gospodarce (mimo szczytnych założeń ich funkcjonowania) odrzucono takie treści.

$\mathrm{Na}$ etapie prekonsultacji niektóre instytucje i urzędy poparły propozycję nowej podstawy programowej z podstaw przedsiębiorczości bez wskazywania uwag. Przykładowo w Zakładzie Ubezpieczeń Społecznych zapoznano się dokładnie z dokumentem i mimo wielu problemów, jakie niesie współczesny system zabezpieczenia społecznego, uznano, że jest on satysfakcjonujący. Uznano tym samym także koncepcję, w której treści z zakresu ubezpieczeń społecznych realizowane są głównie w ramach wiedzy o społeczeństwie, a nie na podstawach przedsiębiorczości. Inne urzędy przesłały zarówno uwagi do dokumentu, jak również informacje akceptujące zapisy.

$\mathrm{Na}$ etapie oficjalnych konsultacji kilku interesariuszy przesłało obszerne pisma, które popierały przyjęte rozwiązania lub nie zawierały żadnych uwag dotyczących nowej podstawy programowej z podstaw przedsiębiorczości (m.in. Ministerstwo Infrastruktury, Biuro Informacji Kredytowej, Zakład Ubezpieczeń Społecznych, Komitet Nauk o Finansach PAN, Dyrektor Generalny Lasów Państwowych, Związek Nauczycielstwa Polskiego, Konferencja Rektorów Akademickich Szkół Polskich, Naczelna Dyrekcja Archiwów Państwowych, Ruch Społeczny Obywatele dla Edukacji).

Ministerstwo Finansów i Rozwoju, Komisja Nadzoru Finansowego oraz Izba Gospodarcza Towarzystw Emerytalnych dostrzegły brak treści związanych z oszczędzaniem na emeryturę. Stąd częściowo uzupełniono te zagadnienia, aby uczeń szkoły średniej docenił wagę oszczędzania na emeryturę. Zasadniczo jednak w wyniku uzgodnień z zespołem 
ekspertów przygotowujących podstawę programową z wiedzy o społeczeństwie problematyka systemu emerytalnego jako części systemu zabezpieczenia społecznego ma być realizowana właśnie na tym przedmiocie, a nie na podstawach przedsiębiorczości. Ponadto Ministerstwo Finansów i Rozwoju proponowało zwiększenie nacisku na zagadnienia dotyczące podatków, które także starano się uwzględnić w miarę możliwości czasowych. Komisja Nadzoru Finansowego podkreśliła wagę rozwijającej się bankowości elektronicznej. W tej grupie znalazły się także osoby prywatne, które sugerowały rozszerzenie wiedzy o różne formy inwestowania, także jako zabezpieczenie inwestora na późniejszy okres jego życia, co zostało w pewnym stopniu uwzględnione.

Ministerstwo Sprawiedliwości nadesłało uwagę obejmującą mediacje i spory sądowe. Uznano to jako częściowo zasadne i wprowadzono te zagadnienia. Krajowa Spółdzielcza Kasa Oszczędnościowo-Kredytowa nadesłała uwagę o braku uwzględniania działalności SKOK-ów, które - jak słusznie zauważono - oferują produkty finansowe takie jak banki. Ponieważ jednak bankami nie są, nauczyciel mógłby pomijać ich istnienie w systemie finansowym. Uwaga ta została uwzględniona. Propozycje nadesłane przez Komisję Krajową NSZZ „Solidarność” w zakresie zadań Państwowej Inspekcji Pracy oraz roli związków zawodowych zostały uwzględnione w podstawie. Partnerstwo na rzecz Edukacji Finansowej proponowało zapisy dotyczące realizacji projektu ekonomicznego. Jest to istotny element w edukacji podstaw przedsiębiorczości, dlatego został on uwzględniony w wymaganiach i warunkach realizacji ( $\mathrm{z}$ uwagi na choćby kształtowanie takich kompetencji, jak umiejętność argumentowania i pracy w zespole).

Niektóre uwagi nadesłane przez urzędy i instytucje nie mogły być zaakceptowane ze względu na ich obszerny charakter wykraczający poza granice czasowe realizacji przedmiotu. Propozycje Naczelnej Dyrekcji Archiwów Państwowych odnosiły się raczej do historii i wiedzy o społeczeństwie, a postulaty Grupy Zagranica obejmujące kształcenie i rozumienie procesów gospodarczych zachodzących w Polsce na tle sytuacji globalnej odrzucono z uwagi na to, że treści te występują w geografii. Podobnie nie zaakceptowano wielu uwag grupy instytucji finansowych (w tym Polskiej Grupy Ubezpieczeń czy instytucji tworzących Radę Rozwoju Rynku Finansowego) z powodu zbytniego uszczegółowienia zapisów, co nadałoby podstawie programowej charakter szczegółowego programu nauczania lub wręcz celów kształcenia dla konkretnych lekcji. Treści kształcenia z zakresu finansów mają jednak swoje wyraźne miejsce, tworzą osobny dział i faktycznie obejmują wszystkie postulaty, tylko w bardziej ogólnej formie zapisu, która jest stosowana w tego typu dokumencie, jakim jest podstawa programowa. Wiele z przedstawionych propozycji było więc szczegółowym rozwinięciem ogólniejszych zapisów zawartych w podstawie programowej, dlatego z powodzeniem mogą być one wykorzystane przy tworzeniu szkolnych programów nauczania.

Zespół opracowujący nową podstawę programową miał świadomość, że przy ograniczonej, założonej odgórnie liczbie godzin kształcenia przedsiębiorczości włączenie wszystkich propozycji i uwag było niemożliwe. Część propozycji była szczegółowym rozwinięciem ogólniejszych zapisów zawartych w podstawie programowej. Mogą one zostać wykorzystane przy konstrukcji szkolnych programów nauczania. Mimo wielu trudności należy uznać, że system prekonsultacji i konsultacji społecznych pozwolił na wypracowanie ostatecznego, akceptowalnego przez interesariuszy kształtu podstawy programowej z podstaw przedsiębiorczości. 
Na podstawie podejmowanych inicjatyw można też sądzić, że w obliczu zmian zachodzących w gospodarce rynkowej instytucje i organizacje pozarządowe wnoszące uwagi do podstawy programowej wzbogacą nauczycieli tego przedmiotu o materiały i pomoce dydaktyczne obrazujące te dokonania. Duża aktywność różnych podmiotów w tym zakresie wskazuje na ogromne możliwości nauczycieli dotyczące wykorzystania tych materiałów edukacyjnych. Pojawiają się też inicjatywy integrujące, jak np. Ministerstwa Finansów jako koordynatora zespołu roboczego ds. edukacji finansowej Rady Rozwoju Rynku Finansowego czy Fundacji „Warszawski Instytut Bankowości”, która w 2018 r. rozpoczęła realizację projektu „Eduaktywni”, mającego m.in. za cel nie tylko stworzenie nowych materiałów edukacyjnych, ale też działania na rzecz integracji rozproszonych inicjatyw edukacyjnych w celu lepszego dotarcia z nimi do środowiska szkolnego. Oczywiście znaczącą rolę w upowszechnianiu nowej podstawy programowej odgrywają także wydawcy edukacyjni, których autorzy przygotowują podręczniki do przedmiotu podstawy przedsiębiorczości. Z założenia podręczniki te muszą w pełni zawierać treści zapisane w podstawie programowej, co jest prawnym warunkiem dopuszczenia danego podręcznika do użytku szkolnego.

\section{Przedmiot podstawy przedsiębiorczości w szkole średniej}

Przedsiębiorczość w szkole średniej jest realizowana w świetle nowej podstawy programowej przede wszystkim w postaci osobnego przedmiotu podstawy przedsiębiorczości. W wyniku podjętych wcześniej decyzji (rozporządzenie MEN z dn. 28.03.2017) uznano, że ekonomia w praktyce jako przedmiot fakultatywny nie będzie dalej oferowana. W ramowych planach nauczania założono, że na podstawy przedsiębiorczości przeznacza się dwie godziny tygodniowo w cyklu kształcenia, to jest w przypadku absolwentów nowej ośmioletniej szkoły podstawowej w:

- liceum ogólnokształcącym i technikum: po 1 godz. w 2 i 3 klasie, co daje ok. 68 godz. ${ }^{2}$ łącznie,

- branżowej szkole I stopnia: 2 godz. w 1 klasie, tj. ok. 68 godz. łącznie,

- liceum ogólnokształcącym zaocznym: 18 godz. łącznie w 1 klasie (po 9 godz. na semestr),

- szkole policealnej: stacjonarnej - 1 godz. tyg. w 1 klasie (ok. 35 godz.*), zaocznej - 20 godz. łącznie w 1 klasie - tylko w sytuacji, gdy słuchacz nie miał podstaw przedsiębiorczości wcześniej.

Warto zaznaczyć, że ten układ będzie obowiązywał od roku szkolnego 2019/2020 (w praktyce $\mathrm{w}$ liceum i technikum wejdzie więc dopiero $\mathrm{w}$ życie $\mathrm{w}$ roku szkolnym 2020/2021), a absolwenci dotychczasowego gimnazjum realizują podstawy przedsiębiorczości w liceum i technikum wg starych zasad (tj. 2 godz. tygodniowo w 1 klasie), natomiast w branżowej szkole I stopnia w klasie 2 (również 2 godz. tygodniowo), czyli w praktyce do roku szkolnego 2019/2020 (liceum i technikum) oraz 2020/2021 (branżowa szkoła I stopnia).

Wobec powyższego przyjęto założenie, że podstawa programowa dla liceum ogólnokształcącego (w tym zaocznego), technikum (Załącznik 1) i branżowej szkoły I stopnia

\footnotetext{
${ }^{2}$ Kalendarz roku szkolnego wskazuje średnio 36-37 tyg. zajęć po uwzględnieniu świąt i ferii, bez dni wolnych od zajęć edukacyjnych ogłoszonych przez organ prowadzący/dyrekcję, zielonych szkół itp. (np. 2015/2016 - 37, 2016/2017 - 36,7, 2017/2018 - 36,8). Źródło: https://kalendarz-roku-szkolnego.edu.pl
} 
powinna być taka sama pod względem układu treści, celów ogólnych i wymagań szczegółowych, natomiast dla szkoły policealnej stacjonarnej i zaocznej okrojono nieco zapisy wymagań szczegółowych, ograniczając się do tych najważniejszych z punktu widzenia funkcjonowania na rynku pracy i prowadzenia własnego biznesu. Przyjęto bowiem założenie, że słuchacze tych szkół mają już doświadczenie na rynku pracy lub w biznesie.

Za jeden z głównych celów dydaktycznych przedmiotu uznano (rozporządzenie MEN z 30 stycznia 2018 i 26 lipca 2018 r.) przygotowanie uczniów do planowania swojej przyszłości oraz do aktywności zawodowej w roli pracowników najemnych lub osób prowadzących własną działalność gospodarczą. Uczniowie podczas edukacji w szkole średniej nabywają zdolność do czynności prawnych oraz podejmują świadome działania i ważne decyzje w odniesieniu do swojej kariery zawodowej. Zapisy nowej podstawy programowej sprzyjają więc przygotowaniu uczniów do aktywności społecznej i gospodarczej, a także do życia rodzinnego w znaczeniu ekonomicznym. Niezmiernie ważne jest też kształtowanie u uczniów szacunku do wartości będących fundamentem gospodarki rynkowej, takich jak wolność gospodarcza, konkurencja, prywatna własność, oraz społecznie odpowiedzialnego biznesu, a także postaw etycznych w pracy i biznesie oraz - szerzej - w życiu społecznym. Ponadto lekcje podstaw przedsiębiorczości wspierają uczniów w samorozwoju oraz chęci inwestowania w siebie i uczenia się przez całe życie, co ma duże znaczenie w sytuacji dynamicznie zmieniających się warunków otoczenia i rozwoju gospodarki opartej na wiedzy. Dzięki takiemu podejściu do edukacji w zakresie przedsiębiorczości korzyści z tego mają nie tylko sami uczniowie, ale także nauczyciele innych przedmiotów, którym łatwiej pracuje się z uczniami chętnymi do zdobywania wiedzy i nowych umiejętności.

$\mathrm{W}$ nowej podstawie programowej, podobnie jak to ma miejsce $\mathrm{w}$ wielu innych przedmiotach, w szczególności w geografii, cele kształcenia określono w postaci wymagań ogólnych dla wiedzy, umiejętności i stosowania wiedzy w praktyce oraz kształtowania postaw. W starej podstawie programowej były one zapisane w nieco innym układzie, wg treści, a nie kategorii celów. Nowa podstawa programowa w tym zakresie nawiązuje do zasad stosowanych w zapisach Europejskich/Polskich Ram Kwalifikacji, znanych także z wcześniejszego powszechnego wdrożenia w szkolnictwie wyższym. W podstawie programowej dla liceum, technikum i branżowej szkoły I stopnia na 34 cele ogólne najwięcej, tj. 13, dotyczy umiejętności i stosowania wiedzy w praktyce, a 10 - wiedzy. Warto podkreślić, że 11 celów ogólnych odnosi się do kształtowania postaw dotychczas niewystępujących w takim zakresie w podstawie programowej, choć wyraźnie jest to wyartykułowane w europejskiej definicji przedsiębiorczości jako kompetencji kluczowej. Zapisy celów ogólnych są bardziej konkretne, zgodnie z wcześniej formułowanymi postulatami.

Natomiast treści nauczania i odpowiadające im cele szczegółowe kształcenia podzielono na cztery części, które dotyczą problematyki: gospodarki rynkowej, rynku finansowego, rynku pracy oraz przedsiębiorstwa. Te działy uznano za fundamentalne w kształceniu w zakresie tego przedmiotu. Wynika to z przyjętego założenia, że zakres tego przedmiotu powinien być zgodny z powszechnie przyjmowaną, szeroko zakrojoną koncepcją przedsiębiorczości jako kompetencji kluczowej. Uznano, że dzięki wyposażeniu uczniów w wiedzę ekonomiczną i finansową kształtuje się ich umiejętności elastycznego zachowania na rynku pracy i zarządzania oraz rozwija cechy przywódcze, umożliwiające podejmowanie własnej działalności gospodarczej. 
Zaproponowano następujący podział godzinowy i kolejność działów:

- gospodarka rynkowa (min. 8 lekcji),

- rynek finansowy (min. 13 lekcji),

- rynek pracy (min. 12 lekcji),

- przedsiębiorstwo (min. 19 lekcji).

Daje to łącznie 52 godz. lekcyjne, czyli ok. 80\% lekcji do dyspozycji nauczyciela.

Za przyjęciem proponowanej kolejności układu treści przemawia szereg argumentów, m.in.:

- wiedza ekonomiczna i finansowa jest podstawą zachowań biznesowych i na rynku pracy, dlatego działy dotyczące gospodarki rynkowej i finansów powinny być realizowane najpierw,

- problematyka rynku pracy i przedsiębiorstwa powinna być realizowana możliwie najpóźniej, ze względu na dojrzałość uczniów,

- treści z zakresu rynku pracy są bliższe (i nieco łatwiejsze) dla uczniów niż treści z działu przedsiębiorstwo,

- poznanie funkcjonowania lokalnego przedsiębiorstwa w trakcie ćwiczeń terenowych lub spotkania z przedsiębiorcą powinno być realizowane pod koniec edukacji, kiedy uczniowie zdobędą już wiedzę pozwalającą na odpowiednie zadawanie mądrych pytań i będą zdolni do przeprowadzenia obserwacji i wyciągania z nich wniosków analitycznych.

Warto zwrócić uwagę na nowość, jaką jest fakt, że w nowej podstawie programowej oprócz tytułów działów zapisano w sposób precyzyjny treści kształcenia (podobnie uczyniono m.in. w geografii). Wynika to $\mathrm{z}$ tego, że odczytanie ich przez zapisy celów - wymagań szczegółowych nastręczało odbiorcom trudności. Pozostawia to nauczycielowi swobodę wyjścia poza wymagania szczegółowe, do których realizacji.(i tylko do nich) powinien czuć się zobowiązany nauczyciel. Jest to możliwe, gdyż przyjęto założenie, że realizacja zapisów podstawy programowej nie powinna obejmować więcej niż ok. 80\% czasu przeznaczonego na kształcenie, pozostałe $20 \%$ jest więc do dyspozycji nauczyciela.

W dziale pierwszym - Gospodarka rynkowa - wyjaśnia się, czym są, jak funkcjonują i rozwijają się systemy gospodarek rynkowych oraz przedstawia się ich odmienności wynikające $\mathrm{z}$ realizowanych celów, różnej roli państwa i rynku w tych systemach oraz wykorzystywanych przez nie podstawowych czynników wzrostu i rozwoju. Uczniowie dowiadują się, jak w różnych systemach ekonomicznych funkcjonują podstawowe podmioty gospodarki - gospodarstwa domowe i przedsiębiorstwa. W dziale drugim - Rynek finansowy - treści kształcenia odnoszą się do wiedzy dotyczącej podstaw finansów oraz umiejętności związanych z funkcjonowaniem na tym rynku człowieka jako świadomego konsumenta oraz przedsiębiorcy. Celem trzeciego działu - Rynek pracy - jest przygotowanie uczniów do aktywnego zachowania się na rynku pracy. Osiągnięcia uczniów realizowane są przez analizę mocnych i słabych stron każdego z nich, możliwości wyboru drogi zawodowej oraz sytuacji na rynku pracy w celu nabycia umiejętności skutecznego jej poszukiwania. Niezbędne jest tutaj poznanie form zatrudnienia, obowiązków i praw pracownika oraz pracodawcy, jak i innych elementów prawa pracy. W wyniku realizacji tego działu uczeń zrozumie konieczność inwestowania w siebie, będzie potrafił przygotować dokumenty aplikacyjne na konkretne stanowisko, dostrzeże również, że inne osoby, w tym osoby niepełnosprawne, poszukują pracy i ją wykonują. Będzie umiał także ocenić korzyści i koszty wynikające ze współpracy z instytucjami rynku pracy. Szczególne miejsce 
zajmuje dział czwarty - Przedsiębiorstwo - który przeznaczony jest przede wszystkim do realizacji wymagań związanych z pogłębieniem wiedzy na temat funkcjonowania przedsiębiorstwa w otoczeniu wraz z przygotowaniem do prowadzania własnego biznesu. Dlatego na realizację tego działu należy przeznaczyć największą liczbę godzin. Proponuje się oprzeć realizację tego działu na idei biznesplanu lub planowania innego przedsięwzięcia o charakterze ekonomicznym, społecznym lub kulturalnym w formie zespołowej pracy projektowej. Treści kształcenia w tym dziale zostały tak ułożone, aby w trakcie ich realizacji uczniowie zapoznawali się z kolejnymi elementami przygotowywanej pracy projektowej, tj. nabywali wiedzę i umiejętności z zakresu wyboru formy organizacyjno-prawnej, rejestracji, analizy rynku, zarządzania, marketingu oraz spraw finansowych. W obliczu rezygnacji z fakultatywnego przedmiotu ekonomia w praktyce, który jak wynika z obserwacji, był i tak rzadko realizowany w szkołach, elementy praktycznej edukacji biznesowej zostały przeniesione właśnie do tego działu (Rozporzadzenie MEN z 30 stycznia 2018 r.).

W zakresie zapisów wymagań szczegółowych (zakładanych efektów kształcenia) należy podkreślić, iż położono większy nacisk na kształtowanie umiejętności i postaw. W efekcie w nowej podstawie znajduje się więcej wymagań szczegółowych w zakresie umiejętności i kształtowania postaw niż w starej podstawie programowej. Szacunkowo w starej podstawie programowej blisko 2/3 wymagań szczegółowych odnosiło się do wiedzy, a ok. 1/3 do umiejętności (postawy były traktowane zupełnie marginalnie), natomiast w nowej podstawie programowej ok. $30 \%$ wymagań odnosi się do wiedzy, $60 \%$ do umiejętności i stosowania wiedzy w praktyce, a blisko 10\% do kształtowania postaw. Formułując wymagania szczegółowe, starano się zapisywać je w języku efektów kształcenia i położyć nacisk na następujące umiejętności:

- identyfikacja zjawisk i dostrzeganie prawidłowości,

- dyskusja, także na trudne i kontrowersyjne tematy,

- analizowanie i interpretowanie zebranych informacji,

- ocenianie i dostrzeganie różnych aspektów analizowanych zjawisk ekonomicznych w celu kształtowania człowieka myślącego, niepoddającego się manipulacyjnym przekazom z mediów, ideologicznym interpretacjom, fake newsom itp., zdolnego do merytorycznej dyskusji,

- czytania ze zrozumieniem aktów prawnych, umów, ogólnych warunków ubezpieczenia itp.

Szczególne miejsce zajmują wymagania odnoszące się do kształtowania postaw, zwłaszcza odpowiedzialności, uczciwości, otwartości i szacunku. Uczniowie powinni być przekonani, że warto być - nie tylko z punktu widzenia moralnego, ale także ekonomicznego - osobami uczciwymi w pracy i biznesie. Podstawa stwarza więc możliwość kształtowania u uczniów postaw etycznych, a także zachowań prospołecznych. Jest to szczególnie istotne w czasach, gdy wiele pojęć poddawanych jest subiektywizacji i relatywizacji, a klasyczna triada dobro - piękno - prawda uważana błędnie za przestarzałą i nie na współczesne czasy. Niezmiernie ważne jest także formowanie postawy, która pozwala docenić rolę przedsiębiorcy w życiu społeczno-gospodarczym i osiągnięć polskich przedsiębiorstw. Bardzo często bowiem zwraca się uwagę na funkcjonowanie globalnych, zagranicznych koncernów i ich produkty, którymi zachwyca się młodzież, a nie dostrzega się sukcesów polskich przedsiębiorców, w tym odnoszonych na rynkach zagranicznych, i ich często bardzo dobrych, innowacyjnych produktów czy usług. Takie zapisy nawiązują do potrzeby kształtowania postaw nowoczesnego patriotyzmu gospodarczego - z jednej 
strony jako świadomości i poczucia dumy z osiągnięć przedsiębiorców i podmiotów gospodarczych, a z drugiej strony rozumianego jako odpowiedzialność konsumentów i ludzi biznesu za dobrobyt gospodarczy i społeczny kraju.

Należy przy tym zaznaczyć, że wiele treści, które mogłyby wejść w zakres podstaw przedsiębiorczości, znajduje się $\mathrm{w}$ podstawach programowych innych przedmiotów szkolnych ze względu na występowanie korelacji międzyprzedmiotowych. Na szczególną uwagę zasługują tu celowo przyjęte korelacje z wiedzą o społeczeństwie i geografią, a także (w mniejszym stopniu) matematyką, informatyką i historią. Najbardziej precyzyjnie korelacje te przedstawiono w dziale Warunki i sposób realizacji podstawy programowej. Zapisy treści kształcenia i wymagań z podstaw przedsiębiorczości należy więc rozpatrywać w kontekście realizacji innych przedmiotów, zarówno w szkole ponadpodstawowej, jak i na wcześniejszych etapach edukacji, gdzie, jak wykazano we wcześniejszych częściach artykułu, realizowane są treści sprzyjające kształtowaniu postaw przedsiębiorczych. Warto podkreślić także, że w szkołach zawodowych (technikum i branżowa szkoła I stopnia) ważne są korelacje z przedmiotami kształcenia zawodowego. Zaleca się także, aby nauczyciel przedsiębiorczości w takich szkołach uwzględnił specyfikę kształcenia w danym zawodzie.

\section{Wnioski i rekomendacje}

Jak się wydaje, nowa podstawa programowa powinna lepiej sprzyjać kształtowaniu postaw przedsiębiorczych dzieci i młodzieży na podbudowie podstawowej wiedzy ekonomicznej i finansowej, tym samym lepiej przygotowywać do życia we współczesnym świecie. Jej zaletą jest także to, że jest wyrazem nie tyle samych poglądów autorów zespołu ekspertów, ale szerokiego środowiska nauczycieli przedsiębiorczości i innych interesariuszy procesu kształcenia w zakresie przedsiębiorczości, wyrażonych w debatach i dyskusjach podczas spotkań konsultacyjnych, konferencji i zjazdów nauczycieli, a także w ramach prekonsultacji i konsultacji społecznych. Powinno to korzystnie wpłynąć na jej zrozumienie i efektywne wdrożenie w praktyce szkolnej.

Kluczowym elementem w tym wszystkim jest jednak nauczyciel. To nie, nawet najdoskonalsze, zapisy podstawy programowej kształtują postawy przedsiębiorcze uczniów, ile właśnie kompetentny i przedsiębiorczy nauczyciel, który potrafi wyzwalać uczniowski potencjał. Pozostaje więc mieć nadzieję, że podejmą oni trud przygotowania się do realizacji nowych zapisów programowych. Dlatego ważne są kursy doskonalące dla czynnych nauczycieli przedsiębiorczości lub nawet studia podyplomowe oraz odpowiednie materiały dydaktyczne i komentarze do nowej podstawy programowej, w celu wsparcia ich w realizacji tej misji. Warta podjęcia jest inicjatywa, do której zachęcają autorzy, przygotowania artykułów lub scenariuszy zajęć dla nauczycieli z nowych tematów zawartych w podstawie programowej (np. problematyki start-upów i innych innowacyjnych modeli biznesowych) przez specjalistów z poszczególnych obszarów. Konieczne jest także uzupełnianie kadr przez kształcenie nauczycieli na studiach wyższych nauczycielskich (a nie tylko krótkich podyplomowych) z zakresu przedsiębiorczości.

Kluczową sprawą w procesie kształcenia jest jego systematyczność (ciągłość) na różnych etapach edukacji oraz stosowanie odpowiednich form, metod i środków dydaktycznych dostosowanych do zakładanych celów, rozwoju psychofizycznego i możliwości percepcyjnych ucznia. Ponieważ kształtowanie postaw przedsiębiorczych i związanych 
z nimi umiejętności na niższych etapach edukacji leży w rękach nauczycieli innych przedmiotów, ważne jest zrozumienie przez nich idei i zapisów podstawy programowej w tym zakresie. Wartościowe więc wydają się kursy doskonalące nie tylko dla nauczycieli przedsiębiorczości, ale wszystkich nauczycieli w zakresie rozwijania postaw przedsiębiorczych uczniów. Konieczne jest w tym wypadku zrozumienie i akceptacja dyrektorów szkół dla takich inicjatyw, np. przez delegowanie nauczycieli na konferencje, seminaria czy kursy oferowane przez wyższe uczelnie i ośrodki doskonalenia nauczycieli.

Szczególną rolę w procesie kształcenia odgrywa podręcznik szkolny jako podstawowy środek dydaktyczny. Wydaje się, że mimo dostępu do różnych elektronicznych zasobów jego rola nie słabnie. Ze względu na rygorystyczne zasady dopuszczania podręczników do użytku szkolnego przez MEN, podręczniki są ciągle gwarantem przekazywania rzetelnej wiedzy. Dobry podręcznik może, a nawet powinien, być nośnikiem zmian w edukacji w zakresie przedsiębiorczości. Rodzi się tylko pytanie: Jaki to powinien być podręcznik? Jakie jego funkcje powinny dominować? Wydaje się, że ze względu na specyfikę przedmiotu i nacisk na kształcenie umiejętności podręczniki w większym stopniu powinny pełnić funkcje motywacyjne, badawcze, transformacyjne, samokształceniowe i wychowawcze niż tylko te tradycyjnie dominujące - funkcje informacyjne. Konieczny wydaje się także podręcznik (zeszyt) ćwiczeniowy, z oczywistych względów sprzyjający bardziej kształceniu umiejętności.

Warunkiem powodzenia $\mathrm{w}$ realizacji nowych zapisów podstawy programowej jest stosowanie metod kształcenia sprzyjających kształtowaniu umiejętności obserwowania zjawisk i procesów zachodzących w gospodarce, a więc raczej z grupy metod aktywizujących niż podających. Wysoce wskazane wydaje się też wykorzystanie nowych metod i technologii informacyjno-komunikacyjnych do pozyskiwania, gromadzenia, analizowania i prezentowania informacji o procesach społeczno-gospodarczych i funkcjonowaniu przedsiębiorstw. Rekomenduje się także stosowanie w większym zakresie strategii kształcenia akcentującej samodzielność w zdobywaniu informacji, a także organizację różnego typu debat i konkursów.

Warto wykorzystać także możliwość prowadzenia w znacznie większym wymiarze zajęć w terenie, stosowania metody projektu w celu stworzenia warunków do porównania wiedzy książkowej z wiedzą uzyskaną bezpośrednio w trakcie zajęć terenowych. Niezbędna tutaj jest przychylność dyrekcji szkoły i świadomość organów prowadzących, że takie zajęcia wymagają czasem większych nakładów czasu i nakładów finansowych. Bez realnego kontaktu z życiem gospodarczym trudno jednak myśleć o pozytywnych efektach edukacji w zakresie przedsiębiorczości albo choćby zainteresowania uczniów przedmiotem.

Autorzy artykułu zapraszają do dzielenia się swoimi doświadczeniami i uwagami w zakresie wdrażania nowej podstawy programowej przez podane niżej adresy mailowe.

\section{Literatura}

References

Bartoń, M. (2005). Przedsiębiorczość jako przedmiot matury 2008. Przedsiębiorczość - Edukacja, 1, 255-258.

Borowiec, M., Rachwał, T. (2011). Kształtowanie postaw przedsiębiorczych na lekcjach geografii wyzwaniem edukacyjnym w procesach globalizacji. Przedsiębiorczość - Edukacja, 7, 321-332.

Borowiec-Gabryś, M., Kilar, W., Rachwał, T. (2018). Przedsiębiorczość jako kompetencja przyszłości, W: S. Kwiatkowski (red.), Kompetencje przyszłości. Warszawa: FRSE, 68-89. 
Kalita, B. (2014). Przedsiębiorczość jako kompetencja kluczowa w procesie uczenia się przez całe życie. Zeszyty Naukowe Politechniki Ślaskiej. Organizacja i Zarządzanie, 72, 51-64.

Kompetencje kluczowe w uczeniu się przez całe życie. Europejskie Ramy Odniesienia. (2007). Urząd Oficjalnych Publikacji Wspólnot Europejskich, Luksemburg.

Piróg, D., Rachwał, T. (2018). Comics as a tool for a narrative approach in early career counselling: theory versus empirical evidence. British Journal of Guidance \& Counselling (published on-line). DOI: $10.1080 / 03069885.2018 .1538494$

Piróg, D. (2015). Kompetencje z zakresu przedsiębiorczości: rozważania teoretyczne i ich ilustracje w obszarze szkolnictwa wyższego. Przedsiębiorczość - Edukacja, 11, 364-376.

Piróg, D. (2015). ZAMEK. Rozpoznawanie predyspozycji zawodowych. Materialy metodyczno-informacyjne i narzędzia dla nauczycieli, doradców zawodowych, psychologów, pedagogów i rodziców. Warszawa: Nowa Era.

Płaziak, M., Rachwał, T. (2014). The Role of Entrepreneurship in Regional Development Strategies (based on the Polish National Strategy of Regional Development 2010-2020). Europa XXI, 26 , 97-110.

Płaziak, M., Rachwał, T. (2015). „Przedsiębiorczy region” - zarys koncepcji w świetle analizy roli przedsiębiorczości w krajowej strategii rozwoju regionalnego Przedsiębiorczość - Edukacja, 11, 37-49.

Rachwał, T. (2017a). Działalność na rzecz edukacji w zakresie przedsiębiorczości Zakładu Przedsiębiorczości i Gospodarki Przestrzennej Instytutu Geografii Uniwersytetu Pedagogicznego w Krakowie. Przedsiębiorczość - Edukacja, 13, 468-490.

Rachwał, T. (2004). Cele i treści kształcenia przedsiębiorczości w szkołach ponadgimnazjalnych. W: J. Brdulak, M. Kulikowski (red.), Przedsiębiorczość stymulatorem rozwoju gospodarczego. Warszawa: Instytut Wiedzy, 263-270.

Rachwał, T. (2005). Kształtowanie postaw u uczniów na lekcjach przedsiębiorczości. Przedsiębiorczość Edukacja, 1, 137-144.

Rachwał, T. (2006). Kształtowanie postaw przedsiębiorczych w edukacji szkolnej. W: B. Muchacka (red.), Szkoła w nauce i praktyce edukacyjnej, t. II. Kraków: Oficyna Wydawnicza „Impuls”, Akademia Pedagogiczna w Krakowie, 427-434.

Rachwał, T. (2017b). Entrepreneurship in School in the Conditions of the Education System Reform in Poland - a Voice in the Discussion on the Directions of Change. Przedsiębiorczość - Edukacja, 13, 330-339.

Rachwał, T., Kudełko, J., Tracz, M., Wach, K., Kilar, W. (2008). Projekt podstawy programowej podstaw przedsiębiorczości w zakresie rozszerzonym dla liceum ogólnokształcącego, liceum profilowanego i technikum. Przedsiębiorczość - Edukacja, 4, 322-334.

Rozporządzenie Ministra Edukacji Narodowejzdnia 14 lutego 2017 r.w sprawiepodstawy programowej wychowania przedszkolnego oraz podstawy programowej kształcenia ogólnego dla szkoły podstawowej, $w$ tym dla uczniów z niepetnosprawnościa intelektualna $w$ stopniu umiarkowanym lub znacznym, kształcenia ogólnego dla branżowej szkoły I stopnia, kształcenia ogólnego dla szkoły specjalnej przysposabiającej do pracy oraz kształcenia ogólnego dla szkoły policealnej (Dz.U. 2017, poz. 356)

Rozporzadzenie Ministra Edukacji Narodowej z dnia 26 lipca 2018 r. zmieniajace rozporzadzenie w sprawie podstawy programowej wychowania przedszkolnego oraz podstawy programowej kształcenia ogólnego dla szkoły podstawowej, w tym dla uczniów z niepetnosprawnościa intelektualna w stopniu umiarkowanym lub znacznym, kształcenia ogólnego dla branżowej szkoły I stopnia, kształcenia ogólnego dla szkoły specjalnej przysposabiającej do pracy oraz kształcenia ogólnego dla szkoły policealnej (Dz.U. 2018, poz. 1679).

Rozporzadzenie Ministra Edukacji Narodowej z dnia 27 sierpnia 2012 r.w sprawie podstawy programowej wychowania przedszkolnego oraz kształcenia ogólnego w poszczególnych typach szkół. Dz.U. 2012, poz. 977.

Rozporzadzenie Ministra Edukacji Narodowej z dnia 28 marca 2017 r. w sprawie ramowych planów nauczania dla publicznych szkót (Dz.U. 2017, poz. 703).

Rozporzadzenie Ministra Edukacji Narodowej z dnia 30 stycznia 2018 r. w sprawie podstawy programowej kształcenia ogólnego dla liceum ogólnokształcacego, technikum oraz branżowej szkoły II stopnia (Dz.U. 2018, poz. 467). 
Edukacja w zakresie przedsiębiorczości w wychowaniu przedszkolnym, szkole podstawowej... 411

Tracz, M., Rachwał, T. (2007). Przedmiot podstawy przedsiębiorczości - założenia realizacji a przygotowanie nauczycieli, Przedsiębiorczość - Edukacja, 3, 286-296.

Wach, K. (2013). Edukacja na rzecz przedsiębiorczości wobec współczesnych wyzwań cywilizacyjno-gospodarczych. Przedsiębiorczość - Edukacja, 9, 246-257.

Wach, K. (2014). Edukacja dla przedsiębiorczości: pomiędzy przedsiębiorczą pedagogiką a edukacją ekonomiczną i biznesową. Horyzonty Wychowania, 13(28), 11-31.

Wach, K. (2015). Przedsiębiorczość jako czynnik rozwoju społeczno-gospodarczego: przegląd literatury. Przedsiębiorczość - Edukacja, 11, 24-36.

Zalecenie Parlamentu Europejskiego i Rady z dnia 18 grudnia 2006 r. w sprawie kompetencji kluczowych w procesie uczenia się przez całe życie (2006/962/WE). Dziennik Urzędowy Unii Europejskiej, L 394/10, 30.12.2006.

Zioło, Z. (2006). Rola przedsiębiorczości w podnoszeniu konkurencyjności społeczeństwa i gospodarki. Przedsiębiorczoś́́ - Edukacja, 2, 10-17.

Zioło, Z. (2007). Rola przedsiębiorczości w aktywizacji gospodarczej - zarys modelu. Przedsiębiorczość - Edukacja, 3, 10-17.

Zioło, Z. (2009). Rola przedsiębiorczości w kształtowaniu społeczeństwa informacyjnego. Przedsiębiorczość - Edukacja, 5, 10-18.

Zioło, Z. (2012). Miejsce przedsiębiorczości w edukacji. Przedsiębiorczość - Edukacja, 8, 10-23.

Zioło, Z. (2016). Przedsiębiorczość w rozwoju układów lokalnych. Przedsiębiorczość - Edukacja, 12, 6-17. 
Załącznik 1.

Wyciąg z podstawy programowej dla liceum ogólnokształcącego

i technikum w zakresie podstaw przedsiębiorczości

\section{Podstawy przedsiębiorczości}

Zmieniająca się dynamicznie gospodarka i jej otoczenie rynkowe, społeczne, polityczne i kulturowe sprawiają, że podstawowa edukacja ekonomiczna, przygotowująca młodego człowieka do przedsiębiorczego, a zarazem akceptowalnego pod względem moralnym życia w ewoluującym świecie, powinna dokonywać się poprzez kształtowanie aktywnych uczestników gospodarki rynkowej. Uczniowie szkół ponadpodstawowych, wkraczając w dorosłość, znajdą się w warunkach presji konkurencyjnej oraz zróżnicowanych wymagań rynku pracy. Powinni więc posiadać podstawową wiedzę nie tylko z zakresu nauk ścisłych, przyrodniczych i humanistycznych, ale także społecznych, a zwłaszcza ekonomicznych. Wiedza ta daje podstawy do kształtowania umiejętności oraz postaw przedsiębiorczych potrzebnych do funkcjonowania we współczesnej, globalnie uwarunkowanej gospodarce.

Przedmiot podstawy przedsiębiorczości stanowi zatem syntezę wybranych celowo elementów wiedzy z zakresu ekonomii, zarządzania i finansów, wzbogaconej elementami geografii społeczno-ekonomicznej, politologii, socjologii, psychologii oraz prawa. W ramach lekcji podstaw przedsiębiorczości uczniowie zapoznają się z podstawowymi kategoriami, mechanizmami i procesami ekonomicznymi oraz ich uwarunkowaniami instytucjonalnymi, behawioralnymi, kulturowymi i rynkowymi. Postawy przedsiębiorcze i wspierające je umiejętności powinny zatem pośrednio z tej wiedzy wynikać. W procesie kształcenia uczniowie dowiadują się, jak - realizując indywidualne cele ekonomiczne - być przedsiębiorczym, a zarazem społecznie odpowiedzialnym w swoich dążeniach i działaniach.

Przy przyjęciu powyższych założeń edukacyjnych jednym z głównych celów dydaktycznych przedmiotu jest przygotowanie uczniów do planowania swojej przyszłości oraz do aktywności zawodowej w roli pracowników najemnych lub osób prowadzących własną działalność gospodarczą. Uczniowie podczas edukacji w szkole ponadpodstawowej nabywają zdolność do czynności prawnych oraz podejmują świadome działania i ważne decyzje w odniesieniu do swojej kariery zawodowej. Podstawa programowa sprzyja więc przygotowaniu uczniów do aktywności społecznej i gospodarczej, a także do życia rodzinnego w znaczeniu ekonomicznym, dając podstawowe umiejętności konkurencyjnych zachowań na rynku, w tym ponoszenia konsekwencji swoich decyzji.

Zakres przedmiotu jest zgodny z powszechnie przyjmowaną definicją przedsiębiorczości jako kompetencji kluczowej. Uzasadnia to konieczność przyjęcia jego szeroko zakrojonej koncepcji, w której dzięki wyposażeniu uczniów w wiedzę ekonomiczną i finansową kształtuje się ich umiejętności elastycznego zachowania na rynku pracy i zarządzania oraz rozwija cechy przywódcze. Niezmiernie ważne jest także kształtowanie u uczniów szacunku do wartości będących fundamentem gospodarki rynkowej i społecznie odpowiedzialnego biznesu, a także postaw etycznych i gotowości do ich przestrzegania 
w życiu zawodowym i społecznym. Lekcje podstaw przedsiębiorczości wspierają uczniów w samorozwoju oraz chęci inwestowania w siebie i uczenia się przez całe życie, w sytuacji dynamicznie zmieniających się warunków otoczenia i rozwoju gospodarki opartej na wiedzy. Takie szerokie ujęcie przedmiotu jest wyzwaniem edukacyjnym zarówno dla uczniów, jak i dla nauczycieli. Za konieczne w procesie kształcenia uznano nabywanie przez uczniów wiedzy oraz kształtowanie umiejętności i postaw dotyczących: funkcjonowania gospodarki rynkowej, rynku finansowego, rynku pracy oraz przedsiębiorstwa.

\section{Cele kształcenia - wymagania ogólne}

I. Wiedza.

1. Poznanie elementarnych pojęć z zakresu podstaw przedsiębiorczości.

2. Rozumienie istoty przedsiębiorczości oraz poznanie jej roli w gospodarce i życiu człowieka.

3. Wyjaśnianie mechanizmów funkcjonowania gospodarki rynkowej, powiązań między jej podmiotami oraz poznanie roli państwa w procesach gospodarczych.

4. Zaznajomienie się z prawami i instytucjami chroniącymi konsumenta.

5. Rozumienie roli pieniądza, rynków i instytucji finansowych w gospodarce, funkcjonowaniu przedsiębiorstw i życiu człowieka.

6. Poznanie rodzajów podatków, ich wpływu na budżety państwa, przedsiębiorstw i gospodarstw domowych.

7. Dostrzeganie znaczenia ubezpieczeń w działalności gospodarczej i życiu człowieka.

8. Rozumienie funkcjonowania rynku pracy, zasad aktywnego poszukiwania pracy, przygotowania się do rozmowy kwalifikacyjnej, poznanie praw oraz obowiązków pracownika i pracodawcy.

9. Poznanie zasad funkcjonowania przedsiębiorstwa w gospodarce rynkowej, form organizacyjno-prawnych, innowacyjnych modeli biznesowych i procedury rejestracji działalności gospodarczej.

10. Rozumienie zasad zarządzania, roli marketingu oraz społecznej odpowiedzialności w funkcjonowaniu przedsiębiorstwa.

II. Umiejętności i stosowanie wiedzy w praktyce.

1. Wyszukiwanie informacji z różnych źródeł, ich selekcja i analizowanie.

2. Stosowanie w praktyce kluczowych pojęć związanych z przedsiębiorczością.

3. Podejmowanie przemyślanych decyzji na podstawie wskaźników ekonomicznych oraz samodzielne obserwacje zjawisk zachodzących w gospodarce.

4. Odpowiedzialne gospodarowanie pieniędzmi, analizowanie, ocenianie i świadome korzystanie $\mathrm{z}$ usług finansowych oraz inwestowanie kapitału z wykorzystaniem wiedzy na temat praw klienta usług finansowych.

5. Podejmowanie niezależnych, odpowiedzialnych decyzji finansowych w odniesieniu do własnych zasobów.

6. Podnoszenie kompetencji osobistych i społecznych niezbędnych na rynku pracy oraz wzmacnianie motywacji do pracy.

7. Analizowanie oferty rynku pracy, sporządzanie dokumentów aplikacyjnych, dokonywanie autoprezentacji oraz korzystne prezentowanie się podczas rozmowy kwalifikacyjnej. 
8. Rozróżnianie skutków wynikających z nawiązania i rozwiązania stosunku pracy oraz wykonywania czynności na podstawie umów cywilnoprawnych i analizowanie przepisów Kodeksu pracy.

9. Analizowanie otoczenia przedsiębiorstwa, w tym rynku, na którym działa.

10. Projektowanie działań w zakresie zakładania własnego przedsiębiorstwa lub podejmowania innych przedsięwzięć o charakterze społeczno-ekonomicznym.

11. Przygotowanie do prowadzenia własnej działalności gospodarczej.

12. Efektywne uczestniczenie $\mathrm{w}$ pracy zespołowej $\mathrm{z}$ wykorzystaniem umiejętności w zakresie komunikacji interpersonalnej oraz wdrażanie zasad skutecznego przywództwa w organizacji.

13. Rozpoznawanie działań etycznych i nieetycznych w życiu gospodarczym oraz przejawów społecznej odpowiedzialności biznesu.

III. Kształtowanie postaw.

1. Wykorzystanie zdobytej wiedzy ekonomicznej do rozwijania własnej postawy przedsiębiorczej jako jednego z podstawowych warunków aktywnego uczestnictwa w życiu społeczno-gospodarczym, w tym skutecznego wykonywania pracy najemnej i prowadzenia własnej działalności gospodarczej.

2. Korzystanie z szans pojawiających się na rynku, podejmowanie inicjatywy, pomysłowość oraz zdolność do pokonywania barier wewnętrznych i zewnętrznych.

3. Docenianie postaw przedsiębiorczych w życiu codziennym, gotowość do czynnego uczestnictwa w życiu społeczno-gospodarczym kraju oraz współodpowiedzialność za jego rozwój.

4. Docenianie roli przedsiębiorców budujących w sposób odpowiedzialny konkurencyjną gospodarkę oraz dostrzeganie znaczenia wolności gospodarczej i własności prywatnej jako filarów gospodarki rynkowej.

5. Przyjmowanie postaw patriotyzmu gospodarczego, rozumianego jako odpowiedzialność konsumentów i ludzi biznesu za dobrobyt gospodarczy i społeczny kraju.

6. Dostrzeganie konsekwencji działań nieetycznych związanych z finansami, w tym obowiązkami podatkowymi.

7. Kształtowanie w sobie odpowiedzialnych postaw jako przyszłych pracowników i pracodawców oraz należytego wypełnienia obowiązków, a także sprawiedliwego, opartego na prawości i dążeniu do prawdy traktowania pracowników.

8. Kształtowanie proaktywności, odpowiedzialności za siebie i innych oraz umiejętnego godzenia własnego dobra $\mathrm{z}$ dobrem innych ludzi.

9. Zainteresowanie prowadzeniem własnej działalności gospodarczej oraz motywacja do ciągłego samorozwoju i inwestowania w siebie.

10. Kształtowanie postawy otwartości i szacunku do innych osób oraz zdolności podejmowania dialogu i współpracy.

11. Przyjmowanie postaw etycznych, społecznej solidarności i odpowiedzialności w życiu gospodarczym.

\section{Treści nauczania - wymagania szczegółowe}

I. Gospodarka rynkowa: przedsiębiorczość w gospodarce rynkowej, gospodarka nakazowo-rozdzielcza (centralnie planowana) i rynkowa, rodzaje rynków, podmioty 
gospodarki rynkowej, struktury rynkowe, mechanizm rynkowy, fazy cyklu koniunkturalnego, rola państwa w gospodarce, konsument na rynku. Uczeń:

1. identyfikuje cechy człowieka o postawie przedsiębiorczej, rozpoznaje je u siebie oraz określa związek zachowania się osoby przedsiębiorczej z szansami, jakie stwarza gospodarka rynkowa;

2. rozumie rolę umiejętności w zakresie komunikacji interpersonalnej jako elementu postawy przedsiębiorczej oraz stosuje różne formy komunikacji werbalnej i niewerbalnej we współdziałaniu z innymi uczestnikami rynku;

3. dostrzega znaczenie przedsiębiorczości, w tym innowacyjności i kreatywności w życiu osobistym i rozwoju społeczno-gospodarczym w skali lokalnej, regionalnej, krajowej i globalnej;

4. na tle cech gospodarki nakazowo-rozdzielczej (centralnie planowanej) wykazuje zalety gospodarki opartej na mechanizmie rynkowym, doceniając fundamentalne wartości, na jakich się opiera (wolność gospodarcza, prywatna własność);

5. analizuje funkcje rynku i rozróżnia rodzaje rynków;

6. charakteryzuje podmioty gospodarki rynkowej, w tym gospodarstwa domowe i przedsiębiorstwa, określa zależności między nimi, rozróżnia struktury rynkowe: monopol, oligopol, konkurencja monopolistyczna, konkurencja doskonała oraz dostrzega negatywne skutki ograniczonej konkurencji na rynku;

7. wyjaśnia prawo popytu i podaży, posługując się wykresami uwzględniającymi zmianę ceny oraz charakteryzuje czynniki wpływające na popyt i podaz;

8. opisuje zachowania gospodarki w kolejnych fazach cyklu koniunkturalnego, charakteryzuje narzędzia oddziaływania państwa na gospodarkę oraz dyskutuje na temat metod przeciwdziałania zjawiskom kryzysowym w gospodarce krajowej i światowej;

9. wyróżnia podstawowe źródła wpływów i kierunki wydatków budżetu państwa oraz wyjaśnia wpływ deficytu budżetowego i długu publicznego na funkcjonowanie gospodarki;

10. charakteryzuje organizacje i instytucje prokonsumenckie, w tym rzecznika konsumenta i Urząd Ochrony Konkurencji i Konsumentów oraz wyjaśnia zakres ich działania na podstawie materiałów źródłowych;

11. posługując się prawami przysługującymi konsumentom, określa drogę ich egzekwowania, w tym zasady składania reklamacji oraz dostrzega możliwość skorzystania z pozasądowych metod rozwiązywania sporów konsumenckich.

II. Rynek finansowy: pieniądz i jego obieg, instytucje rynku finansowego, formy inwestowania, bank centralny i polityka pieniężna, bankowość komercyjna i spółdzielcza, podatki, ubezpieczenia, umowy bankowe i ubezpieczeniowe, ochrona klienta usług finansowych, etyka w finansach. Uczeń:

1. omawia funkcje i formy pieniądza oraz jego obieg w gospodarce;

2. charakteryzuje instytucje rynku finansowego w Polsce (Narodowy Bank Polski, Komisja Nadzoru Finansowego, Rzecznik Finansowy, Giełda Papierów Wartościowych w Warszawie, Bankowy Fundusz Gwarancyjny, banki komercyjne i spółdzielcze, spółdzielcze kasy oszczędnościowo-kredytowe, towarzystwa funduszy inwestycyjnych, Ubezpieczeniowy Fundusz Gwarancyjny, zakłady ubezpieczeń, podmioty świadczące usługi płatnicze) oraz objaśnia ich znaczenie w funkcjonowaniu gospodarki narodowej, przedsiębiorstw i życiu człowieka; 
3. rozróżnia formy oszczędzania i inwestowania, ocenia je z punktu widzenia ryzyka i przewidywanych zysków oraz przeprowadza symulowaną inwestycję w wybraną formę;

4. charakteryzuje rodzaje papierów wartościowych oraz objaśnia mechanizm inwestowania na giełdzie papierów wartościowych na przykładzie Giełdy Papierów Wartościowych w Warszawie;

5. dyskutuje nad wyborem rodzaju funduszu inwestycyjnego, uwzględniając potencjalne zyski oraz ryzyko wystąpienia strat;

6. dostrzega konieczność wczesnego rozpoczęcia systematycznego oszczędzania i inwestowania środków finansowych na emeryturę;

7. identyfikuje najważniejsze funkcje i zadania Narodowego Banku Polskiego, charakteryzuje instrumenty polityki pieniężnej oraz omawia rolę Rady Polityki Pieniężnej w realizacji celu inflacyjnego poprzez kształtowanie stóp procentowych;

8. 8) analizuje oferty usług banków komercyjnych i spółdzielczych oraz spółdzielczych kas oszczędnościowo-kredytowych w zakresie kont osobistych, kart płatniczych, lokat terminowych, kredytów i pożyczek oraz oferty pozabankowych instytucji pożyczkowych, uwzględniając realną stopę procentową, a także dostrzega zagrożenia i rozumie zasady bezpieczeństwa przy korzystaniu z bankowości elektronicznej;

9. identyfikuje rodzaje podatków według różnych kryteriów oraz wyjaśnia ich wpływ na gospodarkę kraju, przedsiębiorstwa i gospodarstwa domowe;

10. wyjaśnia zasady składania rocznej deklaracji i obliczania podatku dochodowego od osób fizycznych;

11. formułuje argumenty za i przeciw stosowaniu podatku dochodowego progresywnego i liniowego;

12. charakteryzuje rodzaje ubezpieczeń według różnych kryteriów i porównuje oferty zakładów ubezpieczeń na przykładzie ubezpieczenia nieruchomości lub pojazdów mechanicznych, ze szczególnym uwzględnieniem relacji zakresów ochrony oraz sum ubezpieczeń do wysokości składki;

13. krytycznie analizuje przykładową umowę kredytu lub pożyczki;

14. analizuje zapisy ogólnych warunków ubezpieczenia na przykładzie ubezpieczenia na życie lub ubezpieczenia od następstw nieszczęśliwych wypadków, identyfikując wyłączenia w treści umów ubezpieczeniowych i przedstawiając ograniczenia odpowiedzialności zakładu ubezpieczeń;

15. formułuje reklamację do instytucji rynku finansowego i pisze skargę do Rzecznika Finansowego na przykładzie wybranego produktu finansowego;

16. jest świadomy, że należy korzystać z różnorodnych i wiarygodnych źródeł informacji przed podjęciem decyzji finansowych;

17. ocenia przykłady praktyk i zachowań etycznych oraz nieetycznych na rynku finansowym.

III. Rynek pracy: mierniki i wskaźniki, popyt i podaż na rynku pracy, kariera zawodowa, poszukiwanie pracy, rozmowa kwalifikacyjna, formy zatrudnienia, systemy płac, prawa i obowiązki pracownika i pracodawcy, bhp i organizacja pracy, Państwowa Inspekcja Pracy, związki zawodowe, etyka w pracy. Uczeń:

1. analizuje podstawowe mierniki i wskaźniki rynku pracy, w tym współczynnik aktywności zawodowej, wskaźnik zatrudnienia i stopę bezrobocia; 
2. wyjaśnia mechanizm popytu i podaży na rynku pracy oraz identyfikuje czynniki wpływające na równowagę na rynku pracy;

3. rozpoznaje motywy aktywności zawodowej człowieka oraz analizuje szanse i możliwości rozwoju własnej kariery zawodowej, dostrzegając rolę procesu uczenia się przez całe życie;

4. rozróżnia metody poszukiwania pracy oraz ocenia ich przydatność i efektywność z punktu widzenia własnej ścieżki rozwoju zawodowego;

5. analizuje własne kompetencje i możliwości zdobycia doświadczenia zawodowego w formie wolontariatu, praktyk lub stażu oraz znalezienia pracy na rynku lokalnym, regionalnym, krajowym i międzynarodowym;

6. opracowuje dokumenty aplikacyjne dotyczące konkretnej oferty pracy;

7. przygotowuje się do rozmowy kwalifikacyjnej i uczestniczy w niej w warunkach symulowanych, eksponując swoje zalety oraz dostrzega podstawowe błędy popełniane podczas rozmowy;

8. rozróżnia formy zatrudnienia i rodzaje umów o pracę, określa korzyści z wyboru konkretnej formy i umowy oraz wymienia sposoby rozwiązywania stosunku pracy;

9. charakteryzuje różne systemy płac, rodzaje i formy wynagrodzeń oraz identyfikuje koszty płacy i oblicza wynagrodzenie netto;

10. analizuje prawa i obowiązki pracownika (w tym młodocianego) i pracodawcy oraz omawia specyfikę zatrudnienia osób niepełnosprawnych;

11. na podstawie analizy przepisów Kodeksu pracy wymienia rodzaje urlopów przysługujące pracownikowi;

12. przedstawia zasady dobrej organizacji oraz bezpieczeństwa i higieny pracy na przykładzie konkretnego stanowiska;

13. dostrzega rolę Państwowej Inspekcji Pracy oraz związków zawodowych w ochronie praw pracowniczych, ocenia zachowania etyczne i nieetyczne zarówno pracodawcy, jak i pracowników oraz rozpoznaje przejawy mobbingu i konsekwencje zatrudniania bez umowy.

IV. Przedsiębiorstwo: klasyfikacje przedsiębiorstw, biznesplan, otoczenie przedsiębiorstwa, formy organizacyjno-prawne, procedury rejestracji i likwidacji, źródła finansowania działalności, analiza rynku, zarządzanie przedsiębiorstwem, praca zespołowa, marketing, wynik finansowy, formy opodatkowania, księgowość, negocjacje, etyka w biznesie i społeczna odpowiedzialność przedsiębiorstw, funkcjonowanie przedsiębiorstwa. Uczeń:

1. klasyfikuje przedsiębiorstwa wg kryteriów rodzaju prowadzonej działalności, wielkości i formy własności oraz charakteryzuje innowacyjne modele biznesu, w tym startupy;

2. uzasadnia przydatność sporządzania i przedstawia strukturę biznesplanu oraz objaśnia poszczególne jego elementy;

3. inspirując się doświadczeniami własnymi i znanych przedsiębiorców oraz bazując na zebranych informacjach z rynku, znajduje pomysł na własną działalność gospodarczą lub przedsięwzięcie społeczne, oceniając go pod względem innowacyjności;

4. sporządza w postaci biznesplanu projekt własnego przedsiębiorstwa lub innego przedsięwzięcia o charakterze społeczno-ekonomicznym oraz przedstawia go $\mathrm{w}$ formie pisemnej albo w postaci prezentacji; 
5. analizuje mikro- i makrootoczenie przedsiębiorstwa, identyfikuje mocne i słabe strony oraz szanse i zagrożenia projektowanego przedsięwzięcia, wybierając jego lokalizację;

6. charakteryzuje podstawowe formy organizacyjno-prawne przedsiębiorstw (indywidualna działalność gospodarcza, spółka cywilna, spółki prawa handlowego) i przedsiębiorczości społecznej (w tym spółdzielnia pracy, spółdzielnia socjalna, stowarzyszenie, fundacja) oraz uwzględniając odpowiedzialność prawną i majątkową właścicieli, dobiera formę do projektowanego przedsiębiorstwa lub przedsięwzięcia;

7. przedstawia procedury związane z rejestracją indywidualnej działalności gospodarczej i jej likwidacją;

8. znajduje możliwości finansowania działalności gospodarczej lub projektowanego przedsięwzięcia (w tym ze środków instytucji finansowych, urzędów pracy, funduszy unijnych i venture capital, „aniołów biznesu”) oraz określa funkcje inkubatorów przedsiębiorczości w powstawaniu i rozwoju małych firm, w tym startupów;

9. zbiera, analizuje i prezentuje informacje o rynku, na którym działa przedsiębiorstwo;

10. wyjaśnia istotę procesu zarządzania różnymi zasobami przedsiębiorstwa, w tym zasady skutecznego zarządzania ludźmi oparte na koncepcji przywództwa;

11. stosuje zasady pracy zespołowej, wyjaśnia rolę oraz identyfikuje cechy dobrego lidera i wykonawcy;

12. charakteryzuje główne instrumenty marketingowe, rozumie ich rolę w funkcjonowaniu przedsiębiorstwa oraz wykorzystuje posiadaną wiedzę w tym zakresie do projektowania działań marketingowych w planowanym przedsiębiorstwie lub przedsięwzięciu;

13. wykazując się kreatywnością, projektuje działania promocyjne, uzasadnia ich rolę $\mathrm{w}$ planowanym przedsięwzięciu oraz dyskutuje nad pozytywnymi i negatywnymi przykładami wpływu reklamy na klientów;

14. prognozuje efekty finansowe projektowanego przedsiębiorstwa lub przedsięwzięcia na podstawie zestawienia planowanych przychodów i kosztów;

15. ocenia wady i zalety poszczególnych form opodatkowania indywidualnej działalności gospodarczej w zakresie podatku dochodowego oraz wymienia inne podatki, którymi może być objęty przedsiębiorca;

16. omawia funkcje dowodów księgowych i podstawowe zasady księgowości oraz wypełnia dowody księgowe i książkę przychodów i rozchodów na potrzeby rozliczenia podatku dochodowego;

17. wyjaśnia zasady skutecznych negocjacji, uwzględniając strategię „wygrana-wygrana”, przedstawia przykłady technik manipulacyjnych stosowanych podczas negocjacji oraz podaje negatywne skutki ich stosowania;

18. rozróżnia zachowania etyczne i nieetyczne w biznesie, w tym przejawy korupcji w życiu gospodarczym oraz rozumie istotę i cele społecznej odpowiedzialności przedsiębiorstw;

19. na podstawie danych Głównego Urzędu Statystycznego określa rozmiary „szarej strefy" w Polsce oraz przyczyny i negatywne skutki jej rozwoju;

20. analizuje przebieg kariery zawodowej osoby, która w zgodzie z zasadami etycznymi odniosła sukces jako przedsiębiorca; 
21. dostrzega możliwości rozwoju przedsiębiorstwa i osiągnięcia sukcesu rynkowego przy pełnym poszanowaniu zasad etycznych w biznesie;

22. wyszukuje i analizuje informacje o sukcesach polskich przedsiębiorstw, w tym ze swojego regionu, na rynku krajowym i międzynarodowym, osiąganych zgodnie z prawem i etyką biznesu;

23. obserwuje proces funkcjonowania lokalnego przedsiębiorstwa w trakcie ćwiczeń terenowych lub dyskutuje na tematy związane z prowadzeniem biznesu podczas spotkania z przedsiębiorcą na podstawie informacji o podejmowanych przez niego działaniach innowacyjnych i w zakresie społecznej odpowiedzialności biznesu.

\section{Warunki i sposób realizacji}

Przyjmuje się, że na dział I należy przeznaczyć minimum 8 godz., na dział II - 13 godz., dział III - 12 godz., dział IV - 19 godz., czyli łącznie 52 godz., co stanowi ok. 80\% godz., które ma do dyspozycji nauczyciel. Pozostałe godziny nauczyciel może przeznaczyć na rozszerzenie określonych treści według własnego uznania. Taki rozkład godzin i odpowiadających im wymagań pomiędzy działy wynika z przyjętego założenia, że w nauczaniu przedsiębiorczości fundamentalne są umiejętności związane z podejmowaniem aktywności zawodowej w ramach pracy etatowej lub samozatrudnienia, zaś podstawą tej aktywności jest wiedza ekonomiczna wraz z problematyką funkcjonowania rynku finansowego.

Kształcenie w zakresie przedsiębiorczości powinno rozpocząć się od przedstawienia, czym są, jak funkcjonują i rozwijają się narodowe systemy gospodarek rynkowych. W dziale pierwszym wyjaśnia się ich odmienności wynikające z realizowanych celów, różnej roli państwa i rynku w tych systemach oraz wykorzystywanych przez nie podstawowych czynników wzrostu i rozwoju, takich jak: surowce, praca, inwestycje rzeczowe i kapitałowe, innowacje, handel czy konsumpcja. Uczniowie dowiadują się, jak w tych różnych systemach ekonomicznych funkcjonują podstawowe podmioty gospodarki - gospodarstwa domowe (ze szczególnym uwzględnieniem praw członków tych gospodarstw jako konsumentów na rynku) i przedsiębiorstwa. Stanowi to punkt wyjścia do pokazania, czym są i jak funkcjonują różnego typu przedsiębiorstwa. Jednakże przez wzgląd na rozwój dojrzałości uczniów, szczegółowe przedstawienie, w jaki sposób są tworzone, zarządzane, przekształcane i likwidowane przedsiębiorstwa oraz co z tego wynika dla ich pracowników i właścicieli, zostanie zaprezentowane kolejnych działach - trzecim i czwartym, czyli na dalszym etapie edukacji. Należy wziąć bowiem pod uwagę, że zgodnie z dotychczasowymi doświadczeniami nauczycieli, problematyka ta powinna być wprowadzana jak najpóźniej.

Realizacja działu drugiego i trzeciego służy pokazaniu, jak na kluczowych dla gospodarki rynku finansowym i rynku pracy funkcjonują gospodarstwa domowe i przedsiębiorstwa.

Wyeksponowanie tych dwóch rynków oraz spojrzenie przez ich pryzmat na gospodarkę i przedsiębiorczość wynikają z tego, że uczniowie, tak jak inni uczestnicy rynku, staną się pracownikami albo pracodawcami i będą musieli pozyskiwać środki pieniężne, a następnie świadomie nimi zarządzać, nabywając dobra konsumpcyjne lub czynniki produkcji, oszczędzając je lub inwestując korzystnie i bezpiecznie.

Zatem w dziale drugim Rynek finansowy wymagania odnoszą się do wiedzy dotyczącej podstaw finansów oraz umiejętności związanych $\mathrm{z}$ funkcjonowaniem na tym rynku 
człowieka jako świadomego konsumenta oraz przedsiębiorcy. Podczas realizacji tego działu szczególne ważne jest, by uczeń na realnych przykładach poznawał i dokonywał oceny produktów finansowych oraz podejmował dojrzałe decyzje, rozumiejąc ich rozmaite konsekwencje.

Celem trzeciego działu Rynek pracy jest przygotowanie uczniów do aktywnego zachowania się na rynku pracy. Osiągnięcia uczniów realizowane są przez analizę mocnych i słabych stron każdego z nich, możliwości wyboru drogi zawodowej oraz sytuacji na rynku pracy w celu nabycia umiejętności skutecznego jej poszukiwania. Niezbędne jest poznanie form zatrudnienia, obowiązków i praw pracownika oraz pracodawcy, jak i innych elementów prawa pracy. W wyniku realizacji tego działu uczeń zrozumie konieczność inwestowania w siebie, będzie potrafił przygotować dokumenty aplikacyjne na konkretne stanowisko, dostrzeże również, że inne osoby, w tym osoby niepełnosprawne, poszukują pracy i ją wykonują. Będzie umiał także ocenić korzyści i koszty wynikające ze współpracy z instytucjami rynku pracy.

Dział czwarty Przedsiębiorstwo przeznaczony jest przede wszystkim do realizacji wymagań związanych z pogłębieniem wiedzy na temat funkcjonowania przedsiębiorstwa w otoczeniu wraz z przygotowaniem do prowadzania własnej działalności gospodarczej. Służy temu poznanie zasad i kształtowanie umiejętności sporządzania biznesplanu. Zaleca się, aby jego przygotowanie stanowiło pracę projektową (wykonywaną indywidualnie lub w grupach) na zajęciach trwających przez co najmniej jeden semestr. Treści kształcenia $\mathrm{w}$ tym dziale zostały tak ułożone, aby w trakcie ich realizacji uczniowie zapoznawali się z kolejnymi elementami przygotowywanej pracy projektowej, tj. nabywali wiedzę i umiejętności z zakresu wyboru formy organizacyjno-prawnej, rejestracji, analizy ryn$\mathrm{ku}$, zarządzania, marketingu oraz spraw finansowych. Jako alternatywę dla opracowania planu biznesowego proponuje się opracowanie innego przedsięwzięcia, w planowaniu którego będzie można wykorzystać ideę biznesplanu. Realizacja takiego przedsięwzięcia o dowolnym charakterze, np. ekonomicznym, społecznym, a nawet kulturalnym, artystycznym czy też sportowym, jest dla uczniów niezwykłym doświadczeniem biznesowym. Uczniowie powinni osiągnąć te same efekty kształcenia, co przy planowaniu własnego biznesu, w dodatku wzmacniając je doświadczeniami praktycznymi.

Ze względu na zmieniającą się dynamicznie rzeczywistość, w związku z informatyzacją obiegu wielu dokumentów i ich częste zmiany, w podstawie programowej nie określono zbyt wielu efektów związanych z wypełnianiem różnego typu formularzy, np. poleceń przelewu, faktur czy deklaracji rocznej podatku dochodowego. Decyzję o tym, w jakim zakresie ćwiczyć te umiejętności, pozostawia się nauczycielowi. W celu realizacji niektórych wymagań konieczne jest skorzystanie z pracowni komputerowej z dostępem do Internetu. Zadaniem szkoły jest więc umożliwienie realizacji takich zajęć.

Szczególną rolę w kształceniu w zakresie przedsiębiorczości odgrywają ćwiczenia terenowe $\mathrm{w}$ przedsiębiorstwie, gdzie możliwa jest bezpośrednia obserwacja procesu jego funkcjonowania i zadań poszczególnych działów. Alternatywnie, w przypadku braku możliwości wyjścia do przedsiębiorstwa, proponuje się zorganizowanie spotkania z przedsiębiorcą, w trakcie którego uczniowie mogą dyskutować na tematy związane z funkcjonowaniem przedsiębiorstwa. Jeśli pozwalają na to możliwości organizacyjne, warto zastosować obydwie formy poszerzenia wiedzy w zakresie funkcjonowania przedsiębiorstwa z praktycznego punktu widzenia. Zadaniem szkoły, przy wsparciu organu prowadzącego, jest zapewnienie kontaktów z przedstawicielami życia gospodarczego 
i możliwości realizacji części zajęć poza szkołą w przedsiębiorstwach lub instytucjach otoczenia przedsiębiorczości.

W osiąganiu wielu efektów kształcenia istotną rolę odgrywa kształtowanie umiejętności czytania fragmentów aktów prawnych, takich jak: Kodeks pracy, Kodeks cywilny, czy ustawa o swobodzie działalności gospodarczej. Oczywiście nie jest możliwe, aby uczniowie zapoznawali się na lekcji w całości z tymi aktami prawnymi. Konieczny jest więc staranny, celowy dobór niewielkich fragmentów, np. związanych z urlopami przysługującymi pracownikowi, czy ramami prawnymi funkcjonowania spółki cywilnej. W realizacji tematów związanych z ochroną konsumentów i klientów usług finansowych należy wykorzystać przykładowe umowy, regulaminy, zapisy ogólnych warunków ubezpieczenia itp. i kształtować umiejętność ich analizy. Ważne jest, aby uczeń mający za sobą kształcenie w ramach lekcji podstaw przedsiębiorczości, był przekonany, że nie zawiera umów i nie kupuje produktów finansowych, których nie rozumie i z których warunkami oferty i realizacji nie zapoznał się dokładnie. Podczas realizacji wymagania odnoszącego się do budżetu państwa również można skorzystać z fragmentu ustawy budżetowej lub jej omówienia przygotowywanego z reguły przez Ministerstwo Finansów, dokonując analizy wpływów i wydatków konkretnego budżetu z danego roku.

Przy realizacji poszczególnych tematów, szczególnie tych dotyczących obowiązków pracownika i pracodawcy, finansów i prowadzenia biznesu, należy zwracać uwagę na kształtowanie postaw uczniów związanych głównie z rozumieniem roli etyki w życiu społeczno-gospodarczym. Uczniowie powinni być przekonani, że warto być - nie tylko z punktu widzenia moralnego, ale także ekonomicznego - osobami uczciwymi w pracy i biznesie. Podstawa stwarza więc możliwość kształtowania u uczniów postaw etycznych, a także zachowań prospołecznych. Jest to szczególnie istotne w czasach, gdy wiele pojęć poddawanych jest subiektywizacji i relatywizacji. Niezmiernie ważne jest także formowanie postawy, która pozwala docenić rolę przedsiębiorcy w życiu społeczno-gospodarczym i osiągnięć polskich przedsiębiorstw.

Warto podkreślić też istotne korelacje z innymi przedmiotami, przede wszystkim z:

1. geografią - w zakresie funkcjonowania rynku pracy, ze szczególnym uwzględnieniem bezrobocia oraz znaczenia kapitału ludzkiego w rozwoju gospodarczym, kształtowania się gospodarki opartej na wiedzy i społeczeństwa informacyjnego, mierników i wskaźników rozwoju społeczno-gospodarczego, takich jak Produkt Krajowy Brutto (PKB) i Wskaźnik Rozwoju Społecznego (HDI), uwarunkowań rozwoju gospodarki krajowej i światowej, w tym znaczenia inwestycji krajowych i zagranicznych w rozwoju gospodarczym, procesów integracji gospodarczej na świecie, ze szczególnym uwzględnieniem integracji europejskiej, globalizacji, roli korporacji w gospodarce, procesów deindustrializacji i reindustrializacji, korzyści gospodarczych i społecznych rozwoju przemysłu zaawansowanych technologii, przemian strukturalnych przemysłu Polski, struktury zatrudnienia i PKB w Polsce na tle innych krajów świata oraz handlu międzynarodowego; lekcje geografii sprzyjają również kształtowaniu umiejętności korzystania z różnych źródeł informacji, w tym danych o rozwoju gospodarczym, ich prezentacji w postaci wykresów i map, analizy i interpretacji, a także oceniania procesów gospodarczych zachodzących w Polsce i w różnych regionach świata;

2. wiedzą o społeczeństwie, w ramach której zarówno w szkole podstawowej, jak i ponadpodstawowej realizowane są takie zagadnienia, jak: funkcjonowanie Unii 
Europejskiej, budżety gospodarstwa domowego i jednostek samorządu terytorialnego, funkcjonowanie systemu zabezpieczenia społecznego (ubezpieczeń społecznych i zdrowotnych), metod ograniczania bezrobocia oraz kształtowane umiejętności w zakresie komunikacji interpersonalnej,

3. matematyką, która stanowi podstawę umiejętności związanych z rachunkami, np. obliczania odsetek od lokat bankowych, realnej stopy procentowej, kosztów płacy;

4. informatyką, która rozwija umiejętności przydatne w przedsiębiorstwie i pracy, jak używanie edytora tekstu, w tym ważnej w biznesie korespondencji seryjnej, arkusza kalkulacyjnego (np. do obliczenia stóp procentowych, odsetek, przygotowania części operacyjnej i finansowej biznesplanu), programu do prezentacji, programów graficznych do projektowania logo firmy, ulotek, plakatów, wizytówek itp.;

5. historią wraz z elementami historii gospodarczej, w tym historii pieniądza i bankowości na ziemiach polskich, etapów rozwoju Unii Europejskiej oraz transformacji gospodarczej w Polsce.

Źródło: Rozporządzenie Ministra Edukacji Narodowej z dnia 30 stycznia 2018 r. w sprawie podstawy programowej kształcenia ogólnego dla liceum ogólnokształcącego, technikum oraz branżowej szkoły II stopnia (Dz.U. 2018, poz. 467).

Uwaga: zapisy podstawy programowej do szkoły branżowej i policealnej (oparte na tej samej koncepcji) są dostępne w Rozporządzeniu Ministra Edukacji Narodowej $z$ dnia 26 lipca 2018 r. zmieniającym rozporządzenie w sprawie podstawy programowej wychowania przedszkolnego oraz podstawy programowej kształcenia ogólnego dla szkoły podstawowej, w tym dla uczniów z niepetnosprawnościa intelektualna $w$ stopniu umiarkowanym lub znacznym, kształcenia ogólnego dla branżowej szkoły I stopnia, kształcenia ogólnego dla szkoły specjalnej przysposabiajacej do pracy oraz kształcenia ogólnego dla szkoły policealnej (Dz.U. 2018, poz. 1679).

Tomasz Rachwal, dr, Uniwersytet Pedagogiczny im. Komisji Edukacji Narodowej w Krakowie, Instytut Geografii, Zakład Przedsiębiorczości i Gospodarki Przestrzennej. Dyrektor Instytutu, kierownik Zakładu, pełni m.in. funkcje: pełnomocnika rektora UP ds. przedsiębiorczości, wiceprzewodniczącego Komisji Geografii Przemysłu Polskiego Towarzystwa Geograficznego, zastępcy redaktora naczelnego czasopism: „Przedsiębiorczość - Edukacja”, „Prace Komisji Geografii Przemysłu Polskiego Towarzystwa Geograficznego” oraz członka redakcji „Entrepreneurial Business and Economics Review”, „Geographia Polonica” oraz „Annales Universitatis Paedagogicae Cracoviensis. Studia Geographica”. Jest autorem lub współautorem podręczników szkolnych i akademickich z zakresu geografii ekonomicznej i przedsiębiorczości. Jego zainteresowania badawcze skupiają się przede wszystkim na problematyce przemian struktur przestrzennych przemysłu, funkcjonowania różnych branż działalności gospodarczej, restrukturyzacji przedsiębiorstw oraz roli przedsiębiorczości w rozwoju układów przestrzennych, a także edukacji w zakresie przedsiębiorczości.

Tomasz Rachwal, PhD, Pedagogical University of Cracow, Institute of Geography, Department of Entrepreneurship and Spatial Management. Director of Institute, Head of the Department, Rector's Proxy for Entrepreneurship, a deputy chair of the Industrial Geography Commission of the Polish Geographical Society, A Deputy Editor in Chief of the following journals: "Entrepreneurship - Education", "Studies of the Industrial Geography Commission of the Polish Geographical Society", and a member of the editorial board of "Entrepreneurial Business and Economics Review", "Geographia Polonica”, "Annales Universitatis Paedagogicae Cracoviensis. Studia Geographica”. The author or co-author of school and academic textbooks on economic geography and entrepreneurship. His 
research interests focus primarily on the issue of change of spatial structures of industry, the functioning of various branches of industrial activity, corporate restructuring and the role of entrepreneurship in the development of spatial systems, as well as entrepreneurship education.

\section{Adres/Address:}

Uniwersytet Pedagogiczny im. Komisji Edukacji Narodowej w Krakowie Instytut Geografii

Zakład Przedsiębiorczości i Gospodarki Przestrzennej

ul. Podchorążych 2

30-084 Kraków, Polska

e-mail: Tomasz.Rachwal@up.krakow.pl

Wioletta Kilar, dr, Uniwersytet Pedagogiczny im. Komisji Edukacji Narodowej w Krakowie, Instytut Geografii, Zakład Przedsiębiorczości i Gospodarki Przestrzennej. Geograf ekonomiczny, adiunkt w Zakładzie Przedsiębiorczości i Gospodarki Przestrzennej Instytutu Geografii Uniwersytetu Pedagogicznego w Krakowie, wicedyrektor ds. dydaktycznych i studenckich Instytutu Geografii. Jej zainteresowania badawcze ukierunkowane są przede wszystkim na procesy kształtowania się i funkcjonowania ponadnarodowych korporacji, globalizacji, przemian struktur przestrzennych przemysłu oraz problematykę nauczania przedsiębiorczości i geografii w szkole.

Wioletta Kilar, PhD, Pedagogical University of Cracow, Institute of Geography, Department of Entrepreneurship and Spatial Management. An economic geographer. She is currently employed as an assistant professor in the Department of Entrepreneurship and Spatial Management in the Institute of Geography at the Pedagogical University of Cracow. She is deputy director of Institute of Geography for Studies and Student Affairs. Her research interests focus primarily on the processes of formation and operation of multinational corporations; globalisation; transformation of spatial structures of industry; and issues of teaching entrepreneurship and geography in schools.

\section{Adres/Address:}

Uniwersytet Pedagogiczny im. Komisji Edukacji Narodowej w Krakowie Instytut Geografii

Zakład Przedsiębiorczości i Gospodarki Przestrzennej

ul. Podchorążych 2

30-084 Kraków, Polska

e-mail: Wioletta.Kilar@up.krakow.pl

Zygmunt Kawecki, mgr inż., LXIV Liceum Ogólnokształcące im. Stanisława Ignacego Witkiewicza w Warszawie. Dyplomowany nauczyciel podstaw przedsiębiorczości w kilku warszawskich liceach. Twórca Poligonu Przedsiębiorczości - warsztatów i wydarzeń ekonomicznych organizowanych w LXIV Liceum im. Stanisława Ignacego Witkiewicza w Warszawie. Opiekun merytoryczny kilku laureatów i finalistów Olimpiady Wiedzy Ekonomicznej i Olimpiady Przedsiębiorczości. Od lat przybliża uczniom z pasją realia gospodarki rynkowej. Współzałożyciel i prezes Stowarzyszenia Nauczycieli Przedsiębiorczości i Edukacji Ekonomicznej. Współpracuje z Narodowym Bankiem Polski, Giełdą Papierów Wartościowych, Uniwersytetem Pedagogicznym w Krakowie, Szkołą Główną Handlową, Uniwersytetem Warszawskim, Fundacją Młodzieżowej Przedsiębiorczości oraz Fundacją Warszawski Instytut Bankowości. Jest uczestnikiem cyklicznych spotkań dotyczących polityki finansowej państwa prowadzonych przez Polską Akademię Nauk.

Zygmunt Kawecki, MSc, Stanisław Ignacy Witkiewicz High School no 44 in Warsaw. Diploma Teacher with experience in a number of upper secondary schools in Warsaw. Initiator of "Enterprise Campsite" in Stanisław Ignacy Witkiewicz High School no 44 in Warsaw. He is also 
a supervisor and mentor of some champions and participants of final level of National Entrepreneurship Olympics and Contests. Passionate in making secondary schools students acquainted with the reality of market economy. Founder and the President of Entrepreneurship and Economy Education Teachers Association. Co-operator with Polish National Bank, Warsaw Stock Market, Pedagogical University of Cracow, Warsaw School of Economics, University of Warsaw, Youth Enterprise Entrepreneurship Association and Warsaw Banking Institute Foundation. Participant of bimonthly meetings on financial politics held by the Polish Academy of Sciences.

\section{Adres/Address:}

LXIV Liceum Ogólnokształcące im. Stanisława Ignacego Witkiewicza w Warszawie ul. Elbląska 51

01-737 Warszawa

e-mail: zygmunt.kawecki@wp.pl

Piotr Wróbel, mgr, nauczyciel dyplomowany podstaw przedsiębiorczości i ekonomii w praktyce w VII Liceum Ogólnokształcącym im. Zofii Nałkowskiej w Krakowie, III Społecznym Liceum Ogólnokształcącym im. Juliusza Słowackiego w Krakowie oraz III Prywatnym Liceum Ogólnokształcącym w Krakowie. Doradca zawodowy. Doktorant w Akademii Górniczo-Hutniczej w Krakowie. Członek Zarządu Fundacji „Znaczenie”. Pilot wycieczek krajowych i zagranicznych, rezydent. Jego zainteresowania badawcze ukierunkowane są przede wszystkim na zarządzanie oświatą i zarządzanie w turystyce, jak również na problematykę nauczania przedsiębiorczości w szkole.

Piotr Wróbel, MA, certified teacher of entrepreneurship and economics in practice at Zofia Nałkowska High School no 7 in Krakow, Juliusz Słowacki Community High School no 3 in Krakow and Private High School no 3 in Krakow. Career counsellor. PhD candidate at AGH University of Science and Technology in Krakow. Board member in the Znaczenie Foundation. Tour guide for tours in Poland and abroad. His research is focused on management in education and tourism, as well as entrepreneurship school teaching.

\section{Adres/Address:}

VII Liceum Ogólnokształcące im. Zofii Nałkowskiej w Krakowie ul. Stanisława Skarbińskiego 5

30-071 Kraków

e-mail: wrobus@wp.pl 